ISSN-2199-353X

Online only at http://www.cahij.com/

\title{
SLAVLARIN KÖKENİ VE POLONYA’NIN KURULUŞUNDA BÜYÜK ROL ÜSTLENEN I. MIESZKO DÖNEMI
}

\author{
Abdulhalik BAKIR* \\ Ebru Emine OĞUZ**
}

\section{Özet}

Geçmişleri oldukça eski dönemlere dayanmakta olan Slavların kayıtlı tarihlerinin M.S.VI.yüzyıldan itibaren olduğu bilinmektedir. Dilbilimsel açıdan incelendiğinde ortak bir kökenden geldikleri anlaşılan Slav halkı, eski tarihçilerin bir kısmı tarafından üç ana bölüme ayrılmış; Antalara (Antés) dâhil edilen Polonyalılar ise Batı Slav grubunda yer almaktadır. Pagan inancına sahip olan Polonyalıların 966 yılında Hristiyanlığı seçmeleri ülke adına bir dönüm noktasını teşkil etmektedir. Dük I.Mieszko'nun, Almanya'nın baskısını azaltmanın yanı sıra bazı menfaatleri doğrultusunda yapmış olduğu bu seçim, Polonya'nın geleceğini şekillendiren en önemli faktörlerden biri olmuştur. Zira Polonya, Roma'yı tercih ederek Batılı Slav grubuna katılarak Avrupa ile daha da yakınlaşmıştır. Böylelikle I.Mieszko döneminde yaşanan sosyo-ekonomik gelişmelerin beraberinde ülke, Almanya ile başedebilecek duruma gelmiş ve izolasyon süreci sona ermiştir.

Makalemizde değindiğimiz bir diğer önemli konu başlı̆̆ı da I.Mieszko'nun geçmişine ilişkindir. Ancak ilginç olduğu ölçüde efsanevi özelliklere sahip bu bilgilere kaynakların pek çoğunda yer verilmediği görülmüştür. XII.yüzyıl tarihçilerinden Polonyalı Gallus Anonymus'un kaleme almış olduğu ana kaynak niteliğindeki eseri de bu noktada büyük önem arz etmektedir.

Anahtar kelimeler: Slavlar, Polonya, Hristiyanlık, I.Mieszko.

\footnotetext{
* Prof. Dr. Bilecik Şey Edebali Üniversitesi, Fen Edebiyat Fakültesi, Tarih Bölümü, Öğretim Üyesi.

** Bilecik Şeyh Edebali Üniversitesi, Sosyal Bilimler Enstitüsü, Tarih Anabilim Dalı Doktora Öğrencisi.
} 
ISSN-2199-353X

Online only at http://www.cahij.com/

\title{
ORIGIN OF THE SLAVS, THE MIESZKO I PERIOD THAT PLAYED A MAJOR ROLE IN THE FOUNDATIONS OF POLAND
}

\begin{abstract}
The recorded data of the Slavs, whose histories based upon fairly old periods, began from the VI.century A.D. When the Slavs, who were divided into three main branches by some ancient historians, were studied through linguistic perspective, it was understood that they all derived from common origin. The Poles, belonged to the Antés, were in the group of the Western Slavs. On behalf of Poland's future their choices in 965 about being Christian was a turning point. This choice that Mieszko made to eliminate German's oppression and also for the sake of his interests had a major role in the future of the country. By having chosen Rome, she was included to the Western branch of the Slavs that brought her closer to Europe. Along with the developments in socio-economical fields, Poland became in a position to be able to cope up with Germany and thus her isolation period was over.

Another important issue in our paper is about Mieszko I's past. This information is not mentioned in many sources, is so interesting as well as has a mythical characteristics. The work of the XII. century Polish historian Gallus Anonymus is of a great important in this regard.
\end{abstract}

Key words: Slavs, Poland, Christianity, Mieszko I.

\section{Slavların Kökeni}

'Slav' kelimesi, Ortaçă̆ ve sonrası kaynaklarında sadece yazılı metinlerde mevcuttur. 'Slav' adı İngilizcedeki 'slave' in (köle) yanı sıra Lehçe'de 'aynı dili konuşan topluluk' ve 'sözcük' manalarına da gelen 'słowo' dan gelmektedir. Zira bu yaklaşımı, Lehçe'de Alman anlamını taşıyan 'Niemiecki' yani 'aynı dili konuşmayanlar' ifadesi doğrular niteliktedir (Lukowski \& Zawadzki, 2006: 4). Yunan (Doğu Roma ve Bizans) yazarları VI.yüzyılda, kuzeybatı kıyılarındaki bu halk topluluklarını tanımlamak için Sklavenoi, Sklabenoi gibi ifadeler kullanırken, sonraki dönemlerde Sklabinio, Sklavenoi, Sklaboi, Sthlaboi, Sthlabenoi, Sthlabinoi, Sthlabenoi, Esklabinoi tabirlerini kullanmışlardı. Erken Ortaçağ ve Ortaçağ Latin kaynaklarında ise Batılı Slavlar için Sklaveni, Sclavini Sclavi, Schlavi, Sclavenia, Sclavina ve Sclavania terimlerine rastlanmaktadır. Araplar da dillerinin fonetik yapısıyla uyum sağlaması nedeniyle bu hususta as-Saqaliba ifadesini benimsemişlerdi (Barford, 2001: 28). Sàkleb kelimesinin çoğulu olan Sakâlibe (Saklebîler), Avrupa'nın doğusu ve güneyi ile Asya'nın kuzeyinde yaşayan insanları tanımlamak için kullanılan Yunanca 'sklabos' (Slav, Sloven) isimin Araplaştırılmış halidir. Ortaçağ' da Avrupa'ya göç eden 
ISSN-2199-353X

Online only at http://www.cahij.com/

Slav halkının köleleştirilmesi nedeniyle zamanla 's(k)lave' şekline dönerek köle anlamını kazanmıştır (Özdemir, 2011: 89).

Orta-Doğu Avrupa'da hiçbir etnik grubu gerek tarih öncesi, gerekse tarih boyunca antropolojik anlamda ırksal açıdan tanımlamak pek mümkün değildir. Eski dönemlerde de tıpkı şimdi olduğu gibi ortak bir kültür ve farklı dillere sahip çeşitli etnik gruplar bulunmaktaydı (Halecki, 1980: 13). Bu gruplardan Slavlar Hristiyanlığın ilk dönemlerinde doğuda Dinyeper Havzasına ${ }^{1}$, kuzeydoğuda ise Litvanya'daki Niemen $^{2}$ ve Dvina ${ }^{3}$ Nehirleri boyunca Yukarı Vistül bölgesinde yaşamaktalard ${ }^{4}$ (The Russian Primary Chronicle, ty: 36). Tarihin başlangıcından beri bu bölgede çoğunluğu teşkil eden Slav halkı, söz konusu gruplar arasında merkez ve baskın bir konumdaydı (Halecki, 1980: 14). XIIyüzyılın ünlü Polonyalı tarihçisi Gallus Anonymus Polonya dışındaki Slavların yaşadıkları bölgeyi 'Slavonia' olarak nitelendirmektedir. Anonym, Slavonia'yı şu şekilde aktarmıştır: "Slavonia kuzeyde Danimarka'dan Saksonya 'ya, Trakya 'dan Macaristan'a, aşă̆ bölgedeyse Carinthia 6 'dan Bavyera 'ya kadar olan

\footnotetext{
${ }^{1}$ Dinyeper Havzası: Rusya ile Ukrayna topraklarının bir bölümünü sulayan bir nehir. Diğer adı Özi’dir. İdil (Volga) ve Tuna'dan sonra Avrupa'nın üçüncü uzun akarsu yudur (Penn, 2001: 65).

2 Niemen Nehri (Neman-Nemunas): Beyaz Rusya topraklarından doğarak Litvanya'ya giren ve Klaipeda' da Baltık Denizi’ne dökülen bir nehirdir. Beyaz Rusya'nın en uzun üçüncü, Litvanya'nın ise en büyük nehridir (Roberts, 2011: 3).

${ }^{3}$ Dvina Nehri: Rusya'nın kuzeyinde bir nehir (Penn, 2001: 299).

${ }^{4}$ Julia Swift Orvis ise 'A Brief History of Poland' adlı eserinde konuya ilişkin olarak Asya' dan gelen Slavların İ.S.II. yüzyılda Tuna'dan Romalılar tarafından Karpatlara sürülmüşler. VII.yüzyılda buradan bu kez Avarlar tarafından atılmış ve orta ve güneybatı Avrupa'ya yayılmışlardır. Batı'ya gitmekte olan bir büyük grup, Elbe’ye Almanya tarafindan durdurulmuştur (Batılı Slavlar). Dinyeper nehri ve kolları üzerinde, doğusuna Rusların (Doğulu Slavların) yerleştiği bu Batılı Slavlara Lehler denilir (Orvis, 1916: 21).

5 Saksonya: Almanya'nın doğusunda yer almaktadır. Başkenti Dresden'in yanı sıra Aue, Chemitz, Görlitz, Meissen, Plauen ve Leipzig önde gelen şehirleridir. Saksonya'nın denizle bağlantısını ise Elbe nehri sağlamaktadır (Vincent, 1997: 417).

${ }^{6}$ Carinthia: Avusturya'nın güneyinde yer almaktadır (Anonymus, 2003: 15).

${ }^{7}$ Bavyera: Almanya'nın güneydoğusunda bir eyalet (Merkl, 2012: 9-10).
} 
topraklarıdır. Güneyde ise Akdeniz'de Dalmaçya ${ }^{8}$ dâhil Epir ${ }^{9}$ 'den Hırvatistan, Istria ${ }^{10}$ ve Adriyatik klyılarında son bulur. Burada Adriyatik klyılarından kastedilen, Adriyatik'in Italya'dan ayrıldı̆̆ Venedik ve Aquielall'nın bulunduğu bölgedir (Anonymi, 2003: 15).”

Hint-Avrupa (Arî) menşeli Slavların (Kurat, 1983: 3) kayıtlı tarihi çok eskilere dayanmakla birlikte M.S.VI.yüzyıl itibarıyla başlamaktadır. İ.S.VI ve VII.yüzyıllarla birlikte Doğu Slavları kuzeyde II'men (İlmen) Gölü ${ }^{12}$ 'ne, güneydoğuda Don Nehri ${ }^{13}$ ve Azov Denizi ${ }^{14}$ 'ne kadar yayılmışlar; Balkanların kuzeyi, Elbe ${ }^{15}-$ Saale $^{16}$ hattını kapsayan tüm bölgeyi işgal etmiş; ayrıca Baltık ve Dinyeper Nehri kıyılarına kadar ulaşmışlardı (The Russian Primary Chronicle, ty: 37). Slavlar ortak dille bağlı, ortak köken duygusuna sahip ancak gelenek, görenek ve medeniyet düzeyinde birbirlerinden oldukça farklıydılar. Tüm Slav toplulukları kendi adetleri, atalarından gelen norm ve davranışları muhafaza etmişlerdi (The Russian Primary Chronicle, ty: 38). Oldukça gevşek bir sosyal ve siyasi yapıya sahipti. Bizans kaynaklarından edinilen bilgiler doğrultusunda askeri kaliteleri yüksek olmasına rağmen ok, yay ve kalkandan oluşan silahlarına bakılırsa, askeri teşkilatları zayıf görülmektedir. Buna bağlı olarak aile ve aşiret yapıları hiç gelişmemişti. İlk Slavlar tarıma dayalı bir topluluktu. Sığır

${ }^{8}$ Dalmaçya: Hırvatistan ve Karadağ Adriyatik Denizi kıyısında yer alan güney bölgesine verilen isimdir (Holbach, 2007: 19).

${ }^{9}$ Epir: Yunanistan'ın önemli Arnavut nüfusu bulunan batı kesimi ve Epir Kralı İskender'in doğduğu yerdir (Bevan, 1871: 371).

${ }^{10}$ Istria: Adriyatik Denizi'nin kuzeybatısında yer alan bölgenin en büyük yarımadasıdır (Anonymus, 2003: 15).

${ }^{11}$ Aquiela: Kuzeydoğu İtalya'da Friuli-Venezia Guilia Bölgesi'ne bağlı Udine ili içinde bulunan bir tarihsel yerleşke ve yerel idare itibarıyla bir komündür (Anonymus, 2003: 15)

${ }^{12}$ II'men Gölü: Rusya'nın Novogrod Oblastı sınırları içinde bulunan 982 kilometrekarelik yüzölçümüne sahip bir göl (Simola, 1996: 262).

${ }^{13}$ Don Nehri: Rusya’nın güneydoğusundan doğar ve Azak Denizi'ne dökülür (Penn, 2001: 69).

${ }^{14}$ Azov Denizi (Azak Denizi): Karadeniz'in kuzeydoğusunda yer alan ve Kerç Boğazı ile Karadeniz’e bağlanan Rusya ve Ukrayna'da bulunan bir iç denizdir. Yüzölçümü ise 37.700 kilometrekaredir (Lagutov, 2010: 100).

${ }^{15}$ Elbe: Orta Avrupa'nın en büyük nehirlerinden biri. Çek Cumhuriyeti'nin kuzeyinde Polonya sınırına yakın bin 400 metre yüksekliğindeki Krkonose Dağı'nın zirveye yakın kısmında doğar, Almanya topraklarından geçtikten sonra Kuzey Denizi'ne dökülür (Mangi, 2016:1).

16 Saale: Almanya'da bir nehir. Aynı zamanda Sakson Saale ve Thüringen Saale olarak da bilinir. Elbe'nin sol kıyısıdır. Aşağı Saksonya'daki Saale ile karıştırılmamalıdır (Mc Martin, 2013: 23). 
yetiştiriciliği ve tarımı tercih etmiş olmaları askeri yapılarına rağmen neden tecrübeli silahlı birer süvari olan göçebe işgalciler tarafından kolay lokma olduklarını açıklamaktadır (Dvornik, 1956: 59). İlk yüzyılda 'kuzeyin altını' kehribarı aramak üzere güneyden gelen Romalı tüccarların kayıtlarına göre, Eski Almanya ve Çekoslovakya'yı kuran Slavlar savaşı sevmeyen bir toplumdu. (Zamoyski, 1987: 13). Göçleri, savaşçılar tarafından gerçekleştirilmiş, şiddet içeren bir fetih değil, köylü halkın barışçıl kolonizasyonu olan Slavlar demokratik yaşam biçimleri sayesinde zamanla tüm Avrupa'ya yayılma başarısını göstermişlerdi (Curta, 2001: 7). Tarım ve sığır yetiştiriciliğinde çok gelişmişlerdi. Balıkçılık, avcılık, kürk, balmumu ve bal üretimi sayesinde dış dünyayla ticari ilişkiler kurabiliyorlardı. Mesleki farklılıklar neticesinde ise farklı sosyal gruplar oluşmuştu (Halecki, 1980: 16). II.Justinian döneminden sonra (685'den sonra) Slavlar, Bizans diş politikasında önemli bir yer tutmuşlardır. Öte yandan bu ilişki sayesinde Slavların sanat, kültür ve yaşam tarzları büyük ölçüde Bizans etkisi altında kalmıştır (Bakır, 2008: 578).

Slavların, Yunan medeniyetiyle ilk karşılaşmaları Doğu Roma İmparatorluğu'na karş1 V.yüzyıl sonunda ortaya çıkan isyanları sırasında gerçekleşmişti (Dvornik, 1956: 34). Bu nedenle Tacitus ${ }^{17}$, Pliny ${ }^{18}$ ve Ptolemy ${ }^{19}$ gibi eski dönem tarih ve coğrafyacıları Avrupa'nın bu bilinmeyen kuzeydoğu bölümüne Slav halkına ithafen farklı isimler vermişlerdir. Bu doğrultuda Venedi ${ }^{20}$, Sclaveni $^{21}$ ve Antés ${ }^{22}$ şeklinde üçe ayrılan Slav halkı günümüzdeki Batı, Güney ve Doğu Slavları olarak yapılan ayırımla örtüşmektedir (Halecki, 1980: 14). Ancak bu yerleşimlerin gerçekleştiği tarihler konusunda birtakım anlaşmazlıklar mevcuttur. Yukarıda yer alan bu söylemlere

17 Tacitus (Gaius Cornellius Tacitus): M.S.56-120 yılları arasında Roma'da yaşamış hatip, avukat, senatör ve tarihçidir. Roma Senatosundaki görevleri, Roma tarihi ve imparatorluğun kuzeyindeki Germanialılar üzerine yazdığı eserleriyle tanınır (Tacitus, 1973: 10).

18 Pliny (Gallus Pilnius Secundus Maior): Yazar ve filozof. Pilnius, bilim tarihindeki yerini, dönemine ait bilgileri derlemek amacıyla kaleme aldığı, insanlık tarihinin ilk ansiklopedisi sayılan dev yapıtına borçludur.

19 Ptolemy: Klaudyos Batlaymus- İskenderiyeli Yunan matematikçi, coğrafyacı ve astronom. 85-165 yılları arasında yaşadığı kabul edilmektedir. Geç İskenderiye Dönemi’nde yaşamış ünlü bilim adamlarındandır (ancient.eu/Ptolemy).

20 Venedi: Tacitus'a göre Orta Avrupa'da Vistula Nehri’nin doğusunda yaşayan Hint-Avrupa irkına mensup halk (Kraitsir,1837: 13).

${ }^{21}$ Sclaveni: Bizans dönemi ilk kronikçileri tarafından diğer bir Slav grubu olan Antes ile birlikte Bizans sınırlarında ortaya çıkan barbar halk olarak bahsedilmiştir (Gibbon, 1854: 169).

22 Antés (Antalar): VI.yüzyılda Aşağı Tuna'da Don Nehri ve Karadeniz’in kuzeybatı bölgesinde (günümüz Moldova ve Ukrayna’nın merkezi) yaşamakta olan halk (Gibbon, 1854: 168). 
karşılık günümüzde ise Slavların anayurtlarının Karpatların ${ }^{23}$ kuzeyi olduğu tüm dünyaca kabul edilmektedir. Bunlara ilaveten Slavlar Südet Dağlar1 ${ }^{24}$ ve Elbe’ye ancak Alman kabilelerinin batıya doğru gerçekleştirdikleri büyük göçün ardından ulaşmışlardır. Batı tarihçesinde ise, Alman etkisinin hüküm sürdüğü süreçte Slavların anavatanlarının Vistül'ün doğusu ile sınırlı olmadığı bilgisi ağır basmaktadır. Son arkeolojik çalışmalar, M.Ö.2000 yıllarında yani Neolitik Çağ ${ }^{25}$ 'n sonunda Slavların Pripyat Havzası $^{26}$ ile Karadeniz' in arasında doğudaki yerleşimlerine ek olarak Vistül Ovası'nın tamamı ve Oder' in büyük bölümünü işgal ettiklerini de ortaya koymaktadır (Halecki, 1980: 14).

Slavların, Akdeniz medeniyetlerinin çok uzaklarında yerleşmiş olmaları Yunan ve Romalılar tarafından uzunca bir süre bilinmemelerinin sebebini açıklamaktadır. İlk dönem Yunan tarihçileri arasında sadece Herodot ${ }^{27}$, un, Dinyester ${ }^{28}$, Bug $^{29}$ ve Dinyeper nehirleri civarındaki halk hakkında bilgisi mevcuttu (Dvornik, 1956: 13). Herodot'un ardından Yunan edebiyatında Slavlara ilişkin hiçbir bulguya rastlanmamaktadır. Milattan sonra II.yüzyılda Karpatlara 'Slav Dağları' adını veren, bu bölgede yaşayan

${ }^{23}$ Karpatlar: Doğu Avrupa'da bir dağ silsilesi. Viyana yakınlarında Bratislava'dan başlar. Polonya'nın güneyinden ve Ukrayna'nın güneybatı kesiminden geçer (Földvary, 1988: 75).

24 Südet Dağları: Orta Avrupa'da bir dağ zinciri. Almanya'nın doğusundan Polonya ve Çek Cumhuriyeti'ne kadar uzanır (Stanturf-Madsen, 2005: 610).

${ }^{25}$ Neolitik Çağ (Cilalı Taş Devri): İnsanlık tarihinin yaklaşık yüzde 99'unu oluşturan Paleolitik Dönemin sona ermesiyle başlayan ve Yeni Taş Devri olarak da adlandırılır. M.Ö.8000 ile 5400 yılları arasını kapsamaktadır (Rudgley, 1999: 1).

${ }^{26}$ Pripyat Havzası: Pripyat Nehri Doğu Avrupa' da yaklaşık 761 kilometre uzunluğunda bir nehridir. Dinyeper'e akıp tekrar Ukrayna, Belarus ve Ukrayna'dan doğu akar. Havza alanı ise 121 bin kilometrekaredir (Penn, 2001: 212)).

${ }^{27}$ Herodot: Antik Yunan tarihçi ve yazarı. Gezilerinde gördüğü yer ve insanları anlattığı Herodot Tarihi olarak bilinen eseriyle tanınmaktadır (Derow\&Parker, 2003: 137).

28 Dinyester Nehri: Batı Ukrayna'nın doğusunda, Karpat Dağlarında yer alan ve uzunluğu 1.362 kilometre olan bir nehirdir (Penn, 2001: 67).

${ }^{29}$ Bug Nehri: Ukrayna'nın ortasından batı kesimine doğru akan bir nehirdir. Narev Nehrinin sol koludur. Bug, Ukrayna,-Polonya ve Polonya-Beyaz Rusya sınır hattından geçerek Polonya içlerine akar ve burada Narev'e bağlanır (Verwijmeren\&Wiering, 2007: 145). 
ISSN-2199-353X

Online only at http://www.cahij.com/

bazı toplulukları da Slav olarak nitelendiren Claudius Ptolemy ayrıca Baltık Denizi ${ }^{30}$ 'ni de Vistül ${ }^{31}$ boyunca yerleşmiş olan Slavlara ithaf etmiştir (Dvornik, 1956: 14).

\section{Slavların Filolojik Açıdan Değerlendirilmesi}

Slav halkı ortak dil veya diyalekt kullanmaktaydı. Bu türden ortaklıkları, göç süreçlerindeki yaşam tarzları arasındaki benzerlikleri de destekler niteliktedir. Bunun bir sonucu olarak ise 'Yerli Slavların' (Proto-Slavs) birbiriyle ilişkili topluluklar silsilesi olduğu düşüncesine varılmaktadır. Ayrıca ırksal etnisiteye ilişkin eski tartışmalar artık önemini yitirmiştir; zira Erken Slavların (İlk Slavlar) ayrı bir ırk teşkil ettiklerine dair hiçbir soru işareti yoktur (Barford, 2001: 27). Aşağıda yer alan tablodaki kelimeler yazılışları itibarıyla her ne kadar birbirlerinden farklıymış gibi görünseler de, fonetik açıdan incelendiklerinde hemen hemen hepsinin sesteş sözcükler oldukları ortaya çıkmaktadır. Ayrıca bu kapsamdaki kelimelerin tamamı eşanlamlıdır. Bu noktadan hareketle Slavların aynı kökenden gelmiş oldukları dilbilimsel olarak da ortaya konmaktadir.

\begin{tabular}{|l|l|l|l|l|l|}
\hline & $\begin{array}{l}\text { Proto- } \\
\text { Slavca }\end{array}$ & Lehçe & Çekçe & $\begin{array}{l}\text { Sirp- } \\
\text { Hirvatça }\end{array}$ & Rusça \\
\hline kale & gardb & gród & brad & gràd & górod \\
\hline köşe & bergb & brzeg & breh & brijeg & béreg \\
\hline saman & salma & słoma & slàma & slàma & solóma \\
\hline süt & melko & mleko & mléko & mltjéko & molokó \\
\hline
\end{tabular}

\section{Tablo $1^{32}$}

Dillerinin özellikle fonetik açıdan büyük ölçüde benzerlik gösterdiği yukarıda yer alan Tablo 1'de de açıkça görülmektedir. Dilin ne denli önem arz ettiği noktasından hareketle Slavların yaşam alanları filolojik bazı gerekçelere dayandırılarak da incelenmiştir. Araştırmacılar, Slavların yerleşim alanlarının 'Polesie' olarak bilinen

\footnotetext{
${ }^{30}$ Baltık Denizi: Kuzey Avrupa'da $53^{\circ}$ ile $66^{\circ}$ kuzey enlemleri ile $20^{\circ}$ ile $26^{\circ}$ doğu boylamları arasında yer almaktadır (Voipio, 1981: 1).

31 Vistül: Polonya' da yer alan ve uzunluğu 1.047 kilometre olan bir nehirdir (Pietrzak, 2015: 62).

${ }^{32} \mathrm{Bu}$ tablodan da anlaşılabileceği üzere Slav ülkelerinin dilleri aynı kökenden türemiştir (Barford, 2001: 17).
} 
ISSN-2199-353X

Online only at http://www.cahij.com/

Pripyat Havzasının olduğu konusunda hemfikirdirler. Zira bu doğrultuda yapılan çalışmalara göre Slavların porsuk ağacı, kayın, karaçam gibi ağaç türlerine karşılık gelen terimlere sahip olmamalarına karşın, gürgen ağacı için bir adlandırmaya sahip oldukları anlaşılmıştır. Bu ağaç cinslerinin yetişebildiği iklim koşulları göz önünde bulundurulduğunda, söz konusu veriler ışı̆̆ında Slav ırkının yaşam alanlarının Königsberg ${ }^{33}$ 'den (Kaliningrad) Odessa'ya kadar olduğu anlaşılmaktadır (Dvornik, 1956: 3).

Her ne kadar, aralarında Alman ve Çeklerin de bulunduğu aydınlar başta bu teoriye katılsalar da, bu denli ufak ölçekteki bölgede yüzyıllarca yaşamış olan bir halkın böylesi güçlü olabileceği kafalarında birtakım soru işaretleri yaratmıştır. Çünkü özellikle sahip oldukları yoğun nüfus ve Roma İmparatorluğu'nun güneydoğu Avrupa sınırını zorlamalarının 6. yüzyıldan itibaren Bizans ve Latin yazarlarında yaratmış olduğu şaşkınlığı söz konusu dönemin eserlerinde görmekteyiz. Böylesi önemli bilgileri göz önünde bulunduran bazı arkeologlar, Slavların yaşam alanlarını güneye doğru Pripyat Havzasından Karpatlara ve batıda ise Vistül'e kadar genişletmişlerdir (Dvornik, 1956: 5).

Filolojik bulgulara ters düşse de, tarih öncesi dönemlerde Avrupa iklim şartlarının farklı olduğundan yola çıkarak Slavların anavatanlarının aynı zamanda Elbe ve Oder $^{34}$, Vistül ve Bug ${ }^{35}$ Nehirleri arasındaki bölgeleri de kapsadığı ortaya çıkmıştır. 1920-1938 yılları arasında Polonyalı arkeologların gerçekleştirdikleri kazılarda elde edilen birtakım veriler de bu bilgiyi kanıtlar niteliktedir. Zira bahsi geçen bölge tarih öncesi dönemlerde yoğun bir nüfusun yaşamını uzun süreli olarak idame ettirebilmesi için hiç elverişli değildir. Ayrıca Polonyalı arkeologlar John Szekanowski, L. Kozłowski, J. Kostrzewski ve T. Sulimirski, Slavların Elbe, Oder, Vistül ve Bug Nehirleri arasındaki bölgede konumlandıkları ve 'Lusatian Kültürü'36 (Lusetyan

${ }^{33}$ Königsberg: Rusya’daki Kaliningrad kentinin tarihi adıdır (Hamm, 1993: 117).

34 Oder Nehri: Çek Cumhuriyeti'nden doğarak Avrupa'nın kuzey kesimindeki ovaları sular ve Baltık Denizi’ne dökülür. 850 kilometre uzunluğuyla Vistül'den sonra Polonya'nın ikinci uzun nehridir Penn, 2001: 183).

${ }^{35}$ Bug Nehri: Ukrayna’nın ortasından batı kesimine doğru akan bir nehirdir. Narev Nehrinin sol koludur. Bug, Ukrayna,-Polonya ve Polonya-Beyaz Rusya sınır hattından geçerek Polonya içlerine akar ve burada Narev'e bağlanır (Verwijmeren-Wiering, 2007: 145).

${ }^{36}$ Lusetyan Kültürü: (Lusetya: Bugün Brandenburg’un bir parçası olan tarihi eyalet, Almanya'nın Slav dili konuşulan güneydoğu bölgesi) Bu kültüre dair büyük sorunlardan biri orijin ve evrimleri hakkındadır çünkü bu kültüre ait kalıntıların bir kısmı da güney Bohemya ve Moravya' dan çıkarılmıştır. Kimileri söz konusu kültürü oluşturanların İliryalı ya da Trakyalı olduğunu savunurken, kimileri ise Daha sonra Slavların yerini aldığı, bilinmeyen bir topluluk olduklarını ifade etmektedir. Tarih öncesi haritalara bakıldığında onlardan geriye kalan boşluğun Slavlarca doldurulduğu anlaşılmaktadır. Bu hipotez 
ISSN-2199-353X

Online only at http://www.cahij.com/

Kültürü)' adı altında, günümüz Orta ve Doğu Avrupa müzelerinde sergilenmekte olan çok sayıda -başta kaplar- buluntunun da bu ırka ait olduğu teorisini ortaya atmışlardır (Dvornik, 1956: 8).

Sahip oldukları geniş toprakları istilacılara karşı savunarak kontrol altında tutmakta zorlanan Slavlar bu soruna geçici çare olarak farklı yönlere göç etmişlerdi. İşte bu nedenden ötürü tarih öncesi çağlardan itibaren Avrupa'nın bu bölgesinde yerli halkla ortak yönleri bulunmayan İskitler ${ }^{37}$, Sarmatlar ${ }^{38}$, Gotlar $^{39}$, Alanlar $^{40}$, Hunlar ${ }^{41}$ ve son olarak da Avarlar ${ }^{42}$ hüküm sürmüşlerdi (Halecki, 1980: 17). Gotlar da ilkel Slav toplumu üzerinde çok büyük etkiye sahip bir diğer topluluk olmuştu ve Baltık bölgesinde yerleşmiş olan Slavları iki yüzyıl boyunca egemenlikleri altında tutmuşlardı. Kısa süren Ermanarich dönemi ve Anta yenilgisinin ardından Karadeniz boyunca karşılaştıkları Slavları da kontrol altına almışlardı. Özellikle Doğu Slavları üzerindeki etkileri yadsınamayacak derecede önem arz etmektedir (Dvornik, 1956: 54). Öyle ki söz konusu etki Slav diline Gotlardan geçmiş çok sayıdaki kelimeden de net bir şekilde anlaşılmaktadır. Kılıç, zırh, miğfer gibi askeri terimler; bardak, tabak, şarap,

Slavların nasıl olup da böylesi hızlı şekilde yayılabildiklerine açıklık getirmektedir (Dvornik, 1956: 10). İ.Ö.VII ya da VIII. yüzyıl civarında Avrupa' ya gelen Osetyalı, İran kökenli ve günümüzde Kafkasya'da yaşamakta olan İskitler tarafından Lusetyalılara ait bölgenin tahrip edilmesi birçok sonuca yol açmıştır. Almanlar ve Keltler'i derinden etkilemiştir. Zayıf düşen Almanlar Oder'in ilerisine çekilirken, büyük bir Kelt göç ve yayılması başlamıştır (Dvornik, 1956: 12).

37 İskitler: M.Ö.VIII.yüzyıl ile M.S.III.yüzyıl arasında Avrupa'nın doğusuyla Orta Asya'da Tanrı Dağları ve Fergana Vadisi'ni de içine alan bölgelerde yaşamış göçebe halk (Hinds, 2010: 9).

38 Sarmatlar: Vistül ile İdil Nehirleri arasında, Kafkasya’nın kuzey ve güneydoğusunu da içine alan bölgede M.Ö.VI.yüzyıldan M.S.IV.yüzyıla kadar yaşamış, Doğu İran öbeğine bağlı bir İskit dili olan Sarmatça konuşan göçebe halk (Hins, 2010: 9).

${ }^{39}$ Gotlar: Güney İskandinavya'nın Gotland bölgesinde yaşamış eski bir Cermen kavmidir. II.yüzyıldan Scythia, Dacia ve Pannonia'da yaşamış, III. ve IV.yüzyıllarda Bizans'1 yağma etmiş ve Aryanizmi benimsemişlerdir (Hinds, 2010: 46).

40 Alanlar: İskit-Sarmat kökenli göçebe halk. Milattan önceki dönemlerde bugünkü Kazakistan topraklarında yaşamaktaydılar. Milâdi dönemin başlangıç yıllarında ise Alanların büyük bir bölümü Volga Irmağını geçerek Don Irmağı civarlarına, Kırım ve Kuzey Kafkasya topraklarına gelerek bu bölgelerde uzun yıllar hâkimiyet kurmuşlardır (Hinds, 2010: 71).

41 Hunlar: Kavimler Göçü ve Roma İmparatorluğunu istila etmesiyle bilinen göçebe kavimler topluluğuna verilen ortak addır. Atilla önderliğinde Avrupa Hun İmparatorluğunu kurmuşlardır. (Hinds, 2010: 46)

42 Avarlar: VI.yüzyılın başlarında batıya doğru göçerek Orta ve Doğu Avrupa'da görünmeye başlayan ve Mohaç Ovası merkezli Avar Kağanlığını kurarak IX.yüzyıla kadar ayakta kalan, nüfusunu kökeni bilinmeyen Avrasya göçebelerinin oluşturduğu kabile topluluğudur (Cole, 2011: 28). 
çaydanlık gibi gündelik kelimelerin yanı sıra pulluk, bağ, incir gibi zirai kelimeler bunlardan sadece bazılarıdır. Gotlar ise bu tür terimleri Roma İmparatorluğu'ndan almışlar; Slavlar ile Roma İmparatorluğu ilişkileri imparatorluğun Tuna kıyılarına ulaşarak, Slavlar ile ticari münasebetler kurmasıyla başlamaktadır (Dvornik, 1956: 55).

Yukarıda bahsettiğimiz Slav dillerinin birbirleriyle olan benzerliklerinin yanı sıra İran kökenli çok sayıda kelimeyi de ihtiva etmektedir. Doğu Avrupa ve Orta Asya'da yerleşmiş olan İskitlerin Doğu İran öbeğine ait bir dil olan Sarmatçayı kullanmaları bu hususta etkili olmuştur. Ayrıca Procopius, Menander ve Agathias gibi tarihçilerin alt Tuna ve Kuzeybatı Karadeniz bölgesinde yaşamış erken Slav kabilelerinden biri olan Antaların (Antés) İran orijinli olduklarını ifade etmeleri de Eski Slavcaya İran dilinden geçen sözcüklerin varlığına açıklık getirebilmektedir.

Doğu Slavlarının Pantheon ${ }^{43}$ adına kutsal kabul edilen bir tanrıçaları bulunmaktayd1. 'Mokoš' (Mokosh, Moist, Nemli) adındaki bu tanrıça Rus geleneklerine göre halen popüleritesini korumaktadır (Mother-Moist-Earth, Mati syra zemlja). Bazı araştırmacılar Rusçada 'Ashtarte' ismini alan bu tanrıçanın Yunan karşılığının ise 'Afrodit' olduğu görüşünü benimsemişlerdir. Ancak bahsedilen tanrıçanın İran'daki 'Tanrıça Anahita'dan alınmış olması daha ağır basmaktadır. Sonraları Ahura Mazda ve Mithra ile bir çeşit kutsal üçleme doğrultusunda yeniden şekillendirilerek, Ardvi Sura Ana-hi-ta adını almıştır. 'Ardvi' kelimesinin 'nemli' manasına gelmesi Slav kökenli Mokoš’un İranlı Anahita’nın karşılı̆̆ı olması mümkündür.

Doğulu Slavların inandıkları 'Stribogu' (zenginlik dağıtan) isimli bir diğer tanrı da İran kökeninden gelmektedir (Bóg: Lehçe’de tanrı manasına gelmektedir). İran' daki muadili ise Vedic Bhaga'nın zenginlik veren eşi 'Amsa'dır. Rüzgârlara da isimler takılmıştır. Bunlardan vetru- ki Hint-İran'a (Varta) vetru'yu anımsatmaktadır- ilk Rus kahramanlık destanı olan 'Tale of Igor’s Campaign' de yer almıştır.

Tüm bunların yanı sıra Eski Slav yerel dilinde önemli miktarda, özellikle dini ya da tapınmaya dair, Farsça kökenli kelimeler bulunmaktadır. 'Kutsal' kelimesi Farsçadaki 'svent' ile aynı olup; Slav dilinde barış, toplum, antlaşma anlamlarına gelen 'mir' kelimesi de İran dilindeki 'mithra' ile aynıdır. Bu sözcüklerden bazılarıysa şunlardır: Žrêti: inanmak, vùpiti: feryat etmek, gatati: kehanette bulunmak, bojati se: korkmak, zùvati: dua etmek, vatra: ateş, càsà: kadeh, mogila: mezar höyüğü, goiti: tedavi etmek, sramù: utanç, vina: suç, kajati: cezalandırmak, ray (rai): cennet (Dvornik, 1956: 50-51). Bu kelimelerden türemiş olan sözcüklerin bir kısmı ise halen

\footnotetext{
43 Panteon: Tüm tanrıların tapınağı anlamına gelmektedir (Baldwin, 1806: V).
} 
ISSN-2199-353X

Online only at http://www.cahij.com/

günümüz Leh dilinde kullanılmaktadır, örneğin: korkmak: bac sie, suç: wina, cezalandırmak: ukarac, cennet: raj.

\section{Slav-Baltık İliș kileri}

Slavlar uzunca bir dönem, kendileriyle birlikte büyük Hint-Avrupa uluslar topluluğunu teşkil eden Alman, Baltık, Trakya ${ }^{44}$, Proto-İtalyan ${ }^{45}$, İlirya ${ }^{46}$ ve Yunan halklarıyla komşu olarak varlıklarını sürdürmüşlerdir (Dvornik, 1956: 5). Slav halklarının tarih öncesi dönemlerdeki kültürel yapılarına ilişkin pek az şey bilinmektedir. Ancak eski belgeler, temel kaynaklar, arkeolojik ve dilbilimsel veriler doğrultusunda Slav halklarının birbirlerinin yanı sıra Baltık halkları ile ortak yönleri olmasına karşın farklı özelliklere de sahip olduklarını ortaya koymaktadır. Tarih öncesi erken dönemlerde Slavların büyük olasılıkla üç ya da dört asır boyunca kuzey komşuları olan Baltık halkıyla yakın ilişkileri olduğu bilinmektedir (Halecki, 1980: 14). Ancak, her ne kadar dilbilimciler arasında Baltık ve Slavların ortak lisanları hususunda bir fikir birliği olmasa da, diğer Hint-Avrupa halklarına nispeten daha sıkı münasebetler içerisinde bulundukları bilinmektedir. Çünkü iki gruba ayrıldıkları Bronz Çağ ${ }^{47}$ 'nın ilk dönemlerinde dahi ortak bir kadere sahip olan bu halklardan Baltık halkı, Slavların peşi sıra Orta Doğu Avrupa'nın en önde gelen etnik unsuru olmuştur (Halecki, 1980: 15).

Eski dönemlerde Baltık halkı günümüzde olduğundan çok daha geniş topraklara sahipti (kendi adlarını verdikleri Baltık Denizi'nden Oka Nehri ${ }^{48}$ 'ne kadar). Bu halk ana grup durumundaki, oldukça kalabalık Litvanyalılar ve kuzeydeki Letonyalılara ilave olarak XIII.yüzyıldaki Alman istilaları neticesinde kaybolan eski Prusyalıları da ihtiva etmekteydi. Ancak Baltık halkının tarihteki rolü Slavların ardından yani X.yüzyıldan itibarendir. Baltık halkından ayrılan Slavların, adına proto-Slavik ${ }^{49}$ (yerli

\footnotetext{
44 Trakya halkı: Anavatanları günümüz Macaristan topraklarıydı (Webber, 2001: 48).

45 Proto-İtalyan (Proto-Italian): Yerel İtalyanca (Mazzocco, 1993: 138).

46 İlirya halkı: Antik dönemde Balkanların batısının bir kısmı ve İtalya Yarımadasının güneydoğu kıyılarında yaşamış olan boy gruplarıdır. İliryalıların bölgesi eski Grek ve Roma kayıtlarında İlirya olarak verilmiştir (Mountain, 1997: 83).

47 Bronz Çağı (Tunç Çağı): Antik Avrupa, Asya ve Orta Doğu halklarının hammadde ve alet kültürlerindeki üçüncü evredir. M.Ö.3000 ile M.Ö.1000 yılları arasını kapsamaktadır (britannica.com).

48 Oka Nehri: Orta Rusya'da büyük bir nehirdir. Volga Nehri’nin en büyük sağ koludur. Bin 500 kilometre uzunluğundadır (Caferoğlu, 1933: 278).

49 Proto-Slavik: Ortak-Slav; M.Ö.2000 ile M.S.6. yüzyıla kadarki Slav dilini temsil etmektedir (Olander, 1974: 42).
} 
ISSN-2199-353X

Online only at http://www.cahij.com/

Slavca) denilebilecek etnik ve dilsel bir toplum oluşturdukları ise çelişki yaratan bir diğer konudur (Halecki, 1980: 15).

Yunan tüccar sömürgeciler günümüz Rus topraklarının içlerine kadar ilerleyerek, suyolları vasıtasıyla neredeyse Baltık kıyılarına kadar ulaşmışlar ve ticari ilişkiler kurmuşlardı. Söz konusu münasebet, İ.S.200 yılı civarında, en çok Güney Rusya'ya doğru yayılarak Slavlar ile yakınlaşan İskitlere ${ }^{50}$ faydalı olmuştur. Şayet Ptolemy'nın bahsettiği, günümüz Ukrayna topraklarına yerleşmiş olan bu halk Slav rrkına mensup ise onlar kesinlikle Yunan medeniyeti ile ilişki kuran ilk Slavlar olma özelliğini taşımaktadır (Dvornik, 1956: 20). Baltık ile Karadeniz arasındaki bu ticari ilişki ulusların dikkatlerini kuzeye, daha 1lıman iklime sahip bereketli topraklara, Yunan medeniyeti ve Roma İmparatorluğu'na çevirmelerine neden olmuştu. Bu bölgeler arasında özellikle Dinyeper üzerindeki Kiev ${ }^{51}$ ön plana çıkmaktaydı. Slavların yavaş ancak istikrarlı bir şekilde ulaşmaya çalıştıkları bu merkezin yanı sıra Don $^{52}$ ve Donetsk $^{53}$ bölgesi İskit saldırısının sonrasında Sarmatlar ${ }^{54}$ tarafından kontrol altına alınmıştı. Zaman içerisinde Slav ırkının yerleştiği bu bölgelerde de doğal olarak Slavların siyasi ve kültürel etkileri görülmeye başlamıştır (Dvornik, 1956: 21).

Slavların gerek direnişleri, gerekse kendi yurtlarını kurma çabalarına ilişkin bilgimiz azdır. Karadeniz bozkırlarında tehdit altında olan Antaların, akrabalarından önce bu bölgede bulundukları anlaşılmaktadır. Ostrogotlara ${ }^{55}$ karşı verdikleri mücadelenin trajik sonu oldukça etkileyicidir. Zira liderleri Boz 374 yılında yetmiş askeriyle birlikte çarmıha gerilmiştir. Oldukça güçlü etkiler yaratan bu olay, Orta Doğu Avrupa'daki asırlık ilk özgürlük hikâyesidir (Halecki, 1980: 17).

\section{Slav-Avar İlişkileri}

50 İskitler: M.Ö.VIII. yüzyıl ile M.S.III. yüzyıl arasında Avrupa'nın doğusuyla Orta Asya' da Tanrı Dağları ve Fergana Vadisi’ni de içine alan bölgelerde yaşamış göçebe halk (Hinds, 2010:9).

51 Kiev: Ukrayna’nın başkenti ve en büyük şehridir (britannica.com).

52 Don Nehri: Rusya'da yer almaktadır. Moskova'nın güneydoğusunda Tula olarak adlandırılan bölgeden doğar ve 1.950 kilometre boyunca akarak Azak Denizi’ne dökülmektedir (Penn, 2001: 69).

53 Donetsk: Eski adıyla Stalino. Ukrayna'daki Donetsk yönetim biriminin merkezidir. Çevresindeki kömür madenleri nedeniyle Ukrayna'nın en büyük metalürji merkezlerinden biridir (Kuzio, 2008: 11).

54 Sarmatlar: Vistül ile İdil Nehirleri arasında, Kafkasya’nın kuzey ve güneydoğusunu da içine alan bölgede M.Ö.VI. yüzyıldan M.S.IV. yüzyıla kadar var olan, Doğu İran öbeğine bağlı bir İskit dili olan Sarmatça konuşan göçebe halk (Hinds, 2010: 9).

55 Ostrogotlar: Roma İmparatorluğu'nun son dönemlerinde ortaya çıkmış bir Cermen Kabilesidir. Gotların doğu koludur. M.S.I. yüzyılda Vistül Nehrinin alt kısmına yerleşmişlerdir (Burns, 1991: XIII). 
ISSN-2199-353X

Online only at http://www.cahij.com/

'Avar' in Slavcası olan 'obr', Lehçe'de 'olbrzym' yani, zorba, baskıcı anlamlarını taşımaktadır ${ }^{56}$. Göktürk Kağanlığının kurulmasının ardından (M.S.552) Avarların bir bölümü İdil (Volga) nehrini geçerek Avrupa'ya ulaşmışlard1. 568 yılına gelindiğinde ise Avarlar tarafından merkezi Pannonia ${ }^{57}$ olan büyük bir imparatorluk kurulmuştu. Uzun bir süredir Slavların hüküm sürdüğ̈̈ bu topraklar artık Avarların eline geçmiş ve bu nedenle de Slavlar Avar hâkimiyetine girmişlerdi (Kurat, 1987: 5). Tuna havzasına yerleşen Avarların Slavların geleceğinde son derece önemli rolü bulunmaktadır. Bizans İmparatorluğu'na bağlı olmak istemeyen Slavlar Avar egemenlik ve kimliğini tanımışlardı. Hatta özellikle Bohemya, Elbe ve Polonya'daki Slavlar bu durumu gönüllü olarak tercih etmiş ve Elbe'de Franklara karşı yapılan 561 562 ve 566-567 yıllarındaki mücadelelere katılmışlardı (Dvornik, 1956: 38).

Avarların Slav topraklarındaki sert yönetimleri oldukça uzun sürmüştür. 630 yılında Avarlara karşı olan Samo ilk Slav eyaletini kurmuştur (Halecki, 1980: 17). Bu, her ne kadar bir Çek ülkesi olarak görülse de kısa süreli olan söz konusu gücün Çek, Moravyalı ya da Slovenlere ait olup olmadığı net bir şekilde bilinmemektedir. Çünkü o dönemlerde batı ve güney Slavları henüz birbirlerinden ayrılmamışlardı (Halecki, 1980: 18). Samo ${ }^{58}$ muhtemelen bir Frank tüccarı veya Frank topraklarından gelen bir Latin kökenli Kelt idi. Avarlara tek tepkiyi Batı Slavları olarak adlandırılan Antalar göstermişti. Bazı tarihçilere göre ise Antaların ilk yöneticileri İran asıllı idi. Dönemin Bizans kaynaklarından, Antaların bu Asyalı savaşçıları kontrol altına alabilmek için Bizans ile ittifak kurduğunu öğrenmekteyiz. Avar Komutanı Apsich (Hurbanič, 2019: 56), 602 yılında Bizans ve Antalara karşı, günümüzde Besarabya ${ }^{59}$ olarak bilinen bölgede, bir sefer düzenlemişti. Bu çarpışma, ilk Slav imparatorluğunun sonu olmuş ve böylelikle Antaların adı tarihten tamamen yok olmuştu. Ancak Slavlar taktiklerini bir açıdan değiştirmişti. Bir bölgeyi kuşattıklarında kendilerine, tıpkı Avarların yaptıkları gibi kırsal kesimleri yakıp yıkma ve ganimetlerle geri dönme hususunda sınır tanımıyorlardı. Sağlam yerleşimler kurabilmek için de fazlasıyla çaba sarf ediyorlardı

\footnotetext{
${ }^{56}$ Kurat, adı geçen eserinde Lehçe olan olbrzym kelimesinin anlamını müstebit (zorba, baskıcı) olarak verirken, Lehçe-Türkçe sözlükte dev, muazzam, büyük cüsseli anlamlarını taşıdığı yer almaktadır Antonowicz-Dubiński, 1983: 367).

57 Pannonia (Panunya): Kuzey ve doğusundan Tuna, batısında Noricum ve daha yukarıda İtalya, güneyinden Dalmaçya ve daha aşağıda Moesia eyaletleriyle çevrili olan Roma İmparatorluğu eyaletidir. Günümüzde ise bu eyaletin topraklarının çoğunluğu Macaristan'da olmak üzere Avusturya, Hırvatistan, Sırbistan, Slovenya ve Bosna-Hersek sınırları içerisindedir (Kurat, 1983: 5).

58 Samo: 631-658 arasında Orta Avrupa'da hüküm sürmüş (Kral Samo) Batı Slav kabile birliğini kurmuştur (ancient.eu).

${ }^{59}$ Besarabya: Bugünkü Moldova'nın tarihteki adıdır (Clark, 1927: 309-310).
} 
ISSN-2199-353X

Online only at http://www.cahij.com/

(Dvornik, 1956: 40). Slavların, ilk siyasi göçlerini yabancı orijinli kişilerin liderliğinde gerçekleştirmeleri, onların yabancı unsurlarla olan tarih öncesi münasebetlerinin önemini ortaya koymaktadır. Bahsi geçen bu yabancı unsurlar Doğu Asya ve Batı Germen'den gelmekteydi (Halecki, 1980: 18).

\section{Batılı Slavlar: Antalar (Antés)}

Tarih öncesi süreçlerine bakıldığında İ.Ö.1500-1300 yılları arasındaki Lusatian kültürü ve Roma dönemine doğru ise 'Slavic Pit Grave' ${ }^{60}$ kültürü Slavlar arasındaki farklılaşmayı hızlandırmıştır. Ayrıca Slavların bu farklılaşma ve çeşitli gruplara bölünmesini sağlayan etmenler arasında üç bölgeye doğru genişlemeleri de yer almaktadır (Halecki, 1980: 15). Slavların güney kolu, Karpatları aşarak olabildiğince uzağa ilerlemişti. Hırvat ve Sırpları takip ederek Doğu imparatorluğu sınırlarına yaklaşan Slovenler ise Tuna Ovasından ${ }^{61}$ Doğu Alplerin iç bölgelerine kadar ulaşarak bugünkü Slovenya'dan çok daha geniş bir bölgeyi işgal etmişlerdi. Doğu Slavlarına bakacak olursak, onların tarihte ortaya çıktıkları İ.S.500' den itibaren bin y1l boyunca ne denli geniş bir alana yayıldıklarını ifade edebilmek pek kolay değildir. Büyük bir bölümü Dinyeper'i ${ }^{62}$ aşarak, güneydoğuda Don nehrinin ${ }^{63}$ aşağı kısmına doğru ilerlerken, bir diğer bölümü de kuzeydoğu yönüne ilerlemiştir. 'Antés' (Antalar) ${ }^{64}$ adı verilen ve Slavların anavatanında yaşamakta olan bu gruplar, ilk kolonileşmenin gerçekleştiği alanda batı ve doğu olmak üzere ikiye ayrılmıştır. Ancak daha sonraları bahsi geçen doğulu gruplara 'Rus' adının verilmesi kadar bu grubun günümüzün Ukraynalılar, Beyaz Rutenyalılar ${ }^{65}$ ve Ruslar ya da Büyük Ruslar şeklinde üçe ayrılmaları da bir hayli tartışmalıdır (Halecki, 1980: 16).

\footnotetext{
${ }^{60}$ Pit Grave Culture (Yamna Kültürü): Bronz Çağı döneminde M.Ö.3600-2200 yılları arasında Tuna' dan Ural'a uzanan bölgenin sahip olduğu kültüre verilen addır (Encyclopedia of Indo-European Culture, 1997: 651).

61 Tuna Ovas1: Tuna Havzası- 801,463 kilometrekarelik toplam alanıla İdil Nehrinden sonra Avrupa' nın en büyük ikinci nehir havzasıdır. On ülkeyi kat ederek Karadeniz'e dökülmektedir (Beattie, 1844: 1).

62 Dinyeper Nehri (Özi Nehri): Rusya ile Ukrayna topraklarının bir kısmını sulayan nehir. İdil ve Tuna'dan sonra Avrupa'nın üçüncü uzun nehridir (Penn, 2001: 65).

${ }^{63}$ Don Nehri: Rusya’nın güneydoğusundan doğarak Azak Denizi’ne dökülen nehir (Penn, 2001: 69).

64 Antés: Antalar- VI. yüzyılın alt Tuna ve kuzeybatı Karadeniz bölgesindeki (bugünkü Moldova ve merkezi Ukrayna) erken bir Slav kabilesi (Gibbon, 1854, 168).

65 Beyaz Rutenya: Beyaz Rusya olarak bilinmektedir. Resmi adıyla Belarus Cumhuriyeti'dir. Doğu Avrupa' da bulunan bu devlet, eski bir Sovyetler Birliği ülkesidir. Başkenti ise Minsk’tir (The Ukranian
} 
Kimi tarihçiler Antaları bir Slav halkı olarak tanımlamaktadır. $\mathrm{Bu}$ isim her ne kadar İran kökenli şeklinde addedilse de aslında 'Venedi' terimi ortak bir Hint-Avrupa kökeninden türemiştir ve bir İran ve Slav toplumunun adlarının ortak kökten geliyor oluşu kabul edilebilir bir durumdur. Antalar (Anteś) hakkında pek çok bilgiyi edindiğimiz VI.yüzyıl yazarlarından Jordanes ${ }^{66}$ ve Procopius ${ }^{67}$ aslında bu hususta pek aydınlatıcı sayılmazlar. Jordanes de tıpkı Tacitus, Ptolemy ve Pliny gibi Slavları Venedi, Sclaveni ve Antés olarak üç bölüme ayırmaktadır. Ayrıca Jordanes'in, Antaların Slavlarla aynı dili konuştuğu ifadesi Procopius tarafından da onaylanmaktadır (Dvornik, 1956: 23).

Antalar ve Sarmatlar ${ }^{68}$ tarafından yönetilen Slavlar oldukça yakın komşulardı. Slavların bir kısmının Antalara diğer Slav toplulukları üzerinde üstünlük sağlayabilmeleri için yardımcı oldukları muhtemeldir (Dvornik, 1956: 24). Antaların, bazı seçkin isimlerinden, Bizans tarihçi ve yazarları Procopius, Menander ${ }^{69}$ ve Agathias $^{70}$ İranlı oldukları şeklinde bahsetmektedir. $\mathrm{Bu}$ noktadan hareketle Bizanslıların, Antaları Slav şeklinde nitelendirdikleri kanısına varabilmekteyiz. Şayet Antalar arasında İran unsurlarının herhangi bir karışımı mevcutsa, o dönemde zaten Slavlaşmışlardı (Dvornik, 1956: 24).

Antalar Gotlara muhalefet liderliğini üstlenmişlerdi. Bunun başlica nedeni ise Got Kralı Ermanarich' in ${ }^{71}$ (M.S.350-370) kuzeye ilerlemeden önce Antalara saldırarak, onları egemenliği altına alması, Antalara ait olmayan ve Jordanes'in Sclavini olarak isimlendirdiği Slavların sadece bir bölümünün Gotların yönetimine

Quarterly, 1949: 67) Ayrıca daha geniş bilgi için bkz. Joseph Liechtensztul, "The White Ruthenian Problem in Eastern Europe".

66 Jordanes: VI.yüzyıl Got asıllı Bizanslı bürokrat, hayatının sonraki bölümünde tarih konusuna yönelmiştir. Jordanes Roma tarihi hakkında Romana'yı kaleme almıştır ancak en bilinen eseri Konstantinopolis'te yaklaşık 551 yılında yazılmış 'Getika'dır. Getika'ya ait geniş bilgi için bkz. (Barford, 2001: 6).

67 Procopius: Filistin kökenli Bizanslı tarihçi. İmparator I.Justinianus döneminde yapılan savaşlarda General Belisarus'a eşlik etmiş ve VI. yüzyılın en önemli tarihçisi olmuştur (Cameron, 1985: VIII).

68 Sarmatlar: Vistül ve İdil Nehirleri arasında, Kafkasya’nın kuzeyi ve güneydoğusunu da içine alan bölgede M.Ö.VI. yüzyıldan M.S.IV. yüzyıla kadar yaşayan, Doğu İran öbeğine bağlı bir İskit dili olan Sarmatçayı konuşan göçebe halk ((Hinds, 2010: 9).

69 Menander: Atina Yeni Komedyasının en önemli temsilcilerindendir olan Yunan oyun yazarıdır (ancient.literature.com).

70 Agathias: Bizanslı şair ve tarihçi (De Jong, 1997: 228).

${ }^{71}$ Ermanarich: Got hükümdarı (Marazzi\&Barnish, 2007: 103). 
girmesiydi. Diğer kısmı ise kuzeye göç ederek Novogrod ${ }^{72}$ ' a yerleşmişlerdi. Bu durum, Slavların Gotlar tarafından yönetilme fikrine karşı olduklarını göstermektedir. Ermanarich, günümüzde Polonya'da yaşamakta olan Slavların atalarını -Jordanes'in Venedi şeklinde isimlendirdiği- kendisine itaat etmeye zorlamıştı. Ayrıca Ermanarich, Baltık ve Karadeniz arasında yaşamakta olan tüm Slav, Alman ve bazı Fin topluluklarını kapsayan bir imparatorluk kurmuştu (Dvornik, 1956: 24). Ancak Gotların bu imparatorluğu fazla uzun süreli olmamıştı. Ermanarich' in umutları, Hunlar tarafından gerçekleştirilen, Avrupa' daki ilk Asyalı istilasıyla yerle bir olmuştu. Hunlar Kuzey Çin'in yöneticileriydi. Bir anda panikle batıya doğru ilerleyen Hunlar HintAvrupa topluluklarını aşarak kendilerine Rusya'nın güneyinde yerleşim yeri teşkil ederek Gotlara saldırıya girişmişlerdi (Dvornik, 1956: 25). Eskiçağın sonunda gerçekleşen bu Hun istilası dönemin en önemli olaylarından biriydi. Orta Avrupa' daki düzeni altüst eden Hunlar, Roma İmparatorluğu'nun doğusuna yerleşmelerine müsaade edilen Gotları harekete geçirerek yıkımına büyük katkıda bulunan süreci başlatmış lard 1 (Dvornik, 1956: 26).

\section{Polonya'nın Kuruluşu}

Arkeolojik veriler doğrultusunda Oder ve Vistül'deki yerleşimlerin başlangıcı İ.Ö.200 yılına kadar dayanmaktayd ${ }^{73}$ (Davies, 2005: 34). Ortaçağ' 1 n başlangıcında Polonya'da iki grup yaşamaktaydı: Suków-Dzidzice ve Prague-Korchak. Bu gruplar göçleri ${ }^{74}$ esnasında iki bölgeye yerleşmişlerdi. İlk bölgede Pshevorsk kültürüne sahip yerli halk yaşamaktaydı. Suków-Dziedzice kültürüne sahip Slavların Polonya'ya ait Pomeranya'yı tekrar fethetmelerinin ardından, diğer bölge de şekillenmişti. Yapılan araştırmalara göre Vislan lara ait topraklarda ilk korunaklı yerleşimler ufak prensliklere aitti (Cvijanović, 2013: 308). Geçmişinde çok sayıda efsane barındıran Polonya ulusunun ilk izlerine M.S496 yılında rastlanmaktadır (Rappoport, 1915: 1). Söz konu su efsanelerden biri IX.yüzyıldan önceki dönemlere, sırasılyla Polonya, Çek ülkesi, Rutenya'yı kuran Lech, Czech, Rus isimli Slav kardeşler ve Prens Krak'a aittir. Bizim bu kişilerden özellikle ilgilendiğimiz Lech ve Prens Krak'tır. Lech 'kartal yuvasını' Gniezno'da (gniezno, kuş yuvası anlamına gelmektedir) yaparken; Vistül nehrindeki

\footnotetext{
${ }^{72}$ Novogrod: Rusya'da yer alan önemli şehirlerden biridir. Rusçada yeni şehir anlamına gelmektedir (Rinke, 2017: 14).

${ }^{73}$ Varşova yakınlarında Świdry, Kraków yakınlarında ise Ojców mağaralarında Yontma Taş Devri”ne ait alanlar bulunmasına rağmen Eski Taş Devri izlerine de rastlanmaktadır. İ.Ö.400'den 1800 yılına kadarki Yeni Taş Devri dönemi kültürüne ait karakteristik özeliklerine göre sınıflandırılmış pek çok mutfak eşyası bulunmuştur (Davies, 2005: 34).

${ }^{74}$ Söz konusu göçe ‘Popoli Slavi’ adı verilmektedir (Wolff, 2001: 174).
} 
ISSN-2199-353X

Online only at http://www.cahij.com/

ejderhayı öldüren Prens Krak ise ejderhanın Kraków'da Wawel tepesinde bulunan mağarasının üzerine şatosunu inşa etmiştir. İşte bahsedilen efsaneye göre Polonya bu şekilde kurulmuştur (Davies, 2005-52).

İdrisî ${ }^{75}$, Polonya'yı çok sayıda şehir ve yerleşimin bulunduğu bir bölge şeklinde tanımlamıştı. Bereketli olan bu topraklar nehir, bağ, bahçelerle kaplı olup, ülkeyi Bohemya (Buania), Saksonya (Sasunia) ve Rusya'dan ayıran dağlarla çevrilmişti. Polonya'nın iki önemli akarsuyu olan $\operatorname{Maros}^{76}$ ve Theis ${ }^{77}$ Polonya ile Rusya'y1 kuzeyden güneye ayıran dağların zirvelerinden doğmaktaydı (Cvijanović, 2013: 315). Polonya doğuda Rusya, güneyde Macaristan, doğuya doğru Moravya ve Bohemya, batıda ise Selencia ${ }^{78}$, Pomerania ${ }^{79}$ ve Prusya ${ }^{80}$ gibi üç barbar pagan ulusla komşuydu. $\mathrm{Bu}$ ülkelerle onları Hristiyanlaştırabilmek uğruna daima savaş halinde olmuştu. Oldukça sert ve değişmez geleneklere sahip olan Polonyalılar için inançlı olmak bir hayli önem taşımaktaydı. Erkekler çok eşli ve öldüklerinde eşleri ise dul kalmak yerine kocalarıyla birlikte ölmeyi tercih edebilmektelerdi (Pietrzak,, 2015: 61).

IX.yüzyılda Slavlar üzerindeki Töton baskı ve etkisine bir tek 'Piast' ${ }^{81}$ ailesi karşı çıkmıştı. 842 yılında lider olarak seçilen Piast' ın döneminde Polonya Altın Çağı'nı yaşamıştı (Whitton, 1917: 4). Piast'ın ardından gelen Siemovit de başarılıydı. Özellikle orduyu ıslah etmesi ülke adına pek çok gelişmenin yaşanmasına yol açmıştı. Onun egemenliği süresince Polonya, her biri kendi knezliği ${ }^{82}$ tarafından yönetilen özgür kabilelere bölünmüştü (Whitton, 1917: 5). Piast hanedanlığının kurulduğu

75 İdrisî (1099-1165): Ebû Abdullah Muhammed b. Muhammed Şerif el-İdrsî olarak bilinen ünlü Atrap gezgin, haritacı ve coğrafyacıdır (Şeşen, 2000: 14).

${ }^{76}$ Maros: Romanya, Doğu Karpat Dağlarındaki Haşmaşu Mare Range'de, Olt Nehrinin eteklerine yükselen ve güneydoğu Macaristan'daki Szeged Tisza' ya katılan 789 kilometrelik bir nehirdir (Kiss, 2019: 72).

77 Theis (Tisa ya da Tisza Nehri): Romanya sınırları içinde bulunan dağlardan doğarak bir süre Ukrayna topraklarında akar ve Macaristan'a girer. Burada Slovakya sınırına ufak bir girinti yaparak Sirbistan'da Voyvodina'da Tuna Nehri ile birleşir (Kiss, 2019: 72).

78 Selencia: Pomerania'nın batı bölgesidir (Anonymus, 2003: 13).

79 Pomerania: Deniz kıyısında yaşayan halk manasına gelmektedir (Pomorze-Lehçesi) (Davies, 2005: 27).

${ }^{80}$ Prusya: Aşağı Vistula ve Niemen (Nemunas) Nehri arasında yer alan bölgedir (Anonymus, 2003: 13).

${ }^{81}$ Piast: Dilbilimsel bir teoriye göre 'Piast' Lehçe'deki 'birinin kollarında yatmak' anlamını taşıyan 'piastować' fiilinin karşılığıdır (Davies, 2005: 52):

${ }^{82}$ Knez: Tarihin farklı zamanlarında ve farklı antik Slav topraklarında kraliyet ve asil bir başlık olarak kullanılan tarihi bir Slav terimidir (Akçura, 2016: sy). 
süreçte batıda Charlemagne'nın imparatorluğu üç Frank krallığına bölünmüş; güneyde ise Büyük Moravya kısa da olsa yükselişe geçmişti. Fransa, iç savaş ve Viking ${ }^{83}$ istilaları nedeniyle güçsüz düşerken, İngiltere'de Wessex Kralı Alfred, Danimarka'nın ilerleyişine karşı koyabilme çabasındaydı. Rusya'da Rurik'in Varangiyanlarr ${ }^{84}$ Novogrod'dan Kiev'e bir rota belirlerken, Akdeniz'e bakılacak olursa Bizans, İslam saldırıları ve ikonaklazm ${ }^{85}$ sebebiyle oldukça yıpranmıştı. Balkan topraklarında bulunan Bulgaristan ise bir dönüşüm noktasında bulunmaktaydı. Yine söz konusu süreçte asıl önemli olan ise Hristiyanlığın yayılmaya başlamasıydı. Moravya'da misyonerlik çalışmaları yürüten St. Cyril ${ }^{86}$ ve St. Methodius ${ }^{87}$ kardeşler Vistül kabilelerine ulaşmak üzereydi. Ayrıca Roma ve Konstantinopolis'ten yayılan Hristiyanlık yavaş yavaş Slavlara doğru uzanmaktaydı (Davies, 2005: 52).

$\mathrm{X}$ yüzyıl itibarıyla Slav topraklarında çok önemli gelişmeler yaşanmaktaydı. $\mathrm{Bu}$ doğrultuda ise tüm Slav uluslar1 Alman İmparatoru I.Otto'nun (936-973) muazzam planına göre yeni Metropol Magdeburg ${ }^{88}$ altında toplanacaktı. Bu fikri 962 yılında kabul eden Papa XII.John, Otto'ya tüm Slav bölgelerinde, çıkarları doğrultusunda birer piskoposluk kurma hakkı tanımıştı. Bu suretle Elbe'nin doğusunda, Slav toprakları

83 Viking (Norslar): İskandinavyalı korsan ve tüccar kavimdir. VIII. ve XI.yüzyıllar arasında kuzeybatı Avrupa' da birçok yeri fethetmişlerdir (Jones, 1984: 17).

84 Varangiyanlar: X.yüzyıldan XIV.yüzyıla kadar Bizans imparatorlarının kişisel korumalığını yapan Bizans ordusunun seçkin birliğidir (Bjerg\&Lind\&Sindback, 2013: 8).

85 İkonoklazm (İkona düşmanlığı): Bu terim tam anlamıyla 'tasvir kırıcılık' anlamına gelmektedir. İkona düşmanlığı hareketi ilk olarak, dinsel resimlere tapınmaya, daha sonra da mum ya da tütsü yakmak gibi boş inançlara dayandığı biçiminde yargılanan bazı uygulamalara, hatta bazen Bakire Meryem ve bazı azizler, özellikle de kutsal kalıntılar kültüne dayanan dinsel uygulamalara karşı bir tepki şeklinde ortaya çıkmıştır (Lemerle, 2011: 85), daha ayrıntılı bilgi için bkz. David Talbot Rice, Bizans Tarihi, (Çev. Abdulhalik Bakır, Pınar Ülgen), Ortaçağ Tarih ve Medeniyetine Dair Çeviriler II, Ankara, 2008, s. 641 655 .

86 St. Cyril: 412-424 yılları arasında İskenderiye patriğidir. Roma İmparatorluğu'nun İskenderiye'de gücü ve etkisinin en yüksek olduğu dönemde göreve gelmiştir. Konstantinopolis Patriği Nestorius'un aforoz edildiği ve 431 yılında toplanan Birinci Efes Konsili’nin merkezinde rol almıştır (britannica.com). Daha geniş bilgi için bkz. Thomas G. Weinandy, Daniel A. Keating, The Theology of St. Cyril of Alexandria.

87 St. Methodius (815-885): St. Cyril'in kardeșidir. Slavları evangelize ettikleri için Slavlar tarafından 'havariler' olarak adlandırılmışlardır (britannica.com). Daha geniş bilgi için bkz. Edward G. Farrugia, Christianity Among the Slavs: The Heritage of Saint Cyril and Methodius..

${ }^{88}$ Magdeburg: Almanya' nın kuzeydoğusunda, Saksonya ve Anhalt eyaletinde bulunan en kalabalık kent ve aynı zamanda da bu eyaletin başkentidir. Ortaçağın sonlarına doğru hızla büyüyerek Avrupa'nın en büyük merkezlerinden biri haline gelen şehir, Elbe Nehri'nin kıyısına konumlanmıştır (Abullafia\&Franklin\&Rubin, 1992: 134). 
ISSN-2199-353X

Online only at http://www.cahij.com/

üzerinde etkili olan Alman siyasi ve dini egemenliği kurulmuş oldu. Ancak çok yakın bir gelecekte Almanların üstünlüğünü durduracak iki önemli güç ortaya çıkacaktı: Bohemya Kralı I.Boleslav ve Polonya (Dvornik, 1956: 109).

Ortaçağ'da Hristiyan Birliğine dâhil olan hemen hemen Avrupa ülkelerinin tümünün geçmişi onuncu yüzyıla dayanmaktadır. Bu durum henüz nihai bölünmenin yaşanmadığı Batı ve Doğu Hristiyan birlikleri için de geçerliydi ${ }^{89}$. Tek istisna Batı, 962 yılında Alman krallarının hâkimiyetine geçerek Alman emperyalizmine hizmet eder bir hale dönüşürken, daha eski geleneklere sahip doğudaki Bizans İmparatorluğuydu (Halecki, 1980: 51). Paleodemografik ${ }^{90}$ kanıtlar devlet oluşumu sürecinde bölgedeki ${ }^{91}$ nüfusun üç katına çıktığını ve sonrasında da artmaya devam ettiğini göstermektedir (Barford, 2001: 261). Moravya ${ }^{92}$ 'nın çöküşünün ardından Macarların kuzeyindeki Bohemya $^{93}$ Çekleri ve Elbe-Saale ve Oder-Neisse ${ }^{94}$ hattı arasındaki Slavlar Almanya'nın komşuları haline gelmişti. Pagan ${ }^{95}$ inançlarında 1srarcı olan Slavlar, siyasi bir birlik oluşturabilme konusunda da başarısız olmuşlardı. Söz konusu durum Slav topraklarının Almanlar tarafından fethedilerek, halen pagan inancına sahip, henüz

${ }^{89}$ Slav halklarının kendilerine ait bir kimliğe sahip olmasının nedenlerinden biri Batı düşmanlığıydı. Bu kimliğin oluşmasında din farklılığı da özel bir avantaj sağlamıştı. Ortodoks Hristiyanlığa sıkı biçimde bağlılık, bazı Slav halklarının kimliğinin temelini oluşturdu. Slav devletleri Hristiyanlığı seçmeselerdi, Avrupa'nın bir parçası olarak kabul edilmezdi. Ortodoksluğu değil, Katolikliği tercih etselerdi, tarihlerinde Batı Avrupa ile paylaştıkları noktaların sayısı daha fazla olurdu. Tıpkı Roma'yı yani Katolikliği seçen Polonya gibi (Roberts, 2015: 219).

90 Paleodemografi: Geçmişte yaşamış Popülasyonların özellikle de prehistorik ve protohistorik toplulukların doğum ve ölüm istatistikleriyle ilgilenmektedir. Eski dönemlerden itibaren günümüze gelinceye kadar Popülasyonların nüfus yapılarında görülen değişikliklerinin çok çeşitli zaman ve mekânlarda yaşamını sürdürmüş olan bireylerin iskelet kalıntılarının incelenmesiyle sağlanabilmektedir. Kelime anlamıyla 'eski nüfus bilimi' şeklinde tanımlanabilen paleodemografi dolaylı yönden bağlantılı olan farklı metotlarla çalışsalar dahi bazen paleoantropolojinin, bazen de demografinin bir alt disiplini olarak pek çok demograf ve antropoloğun ilgisini çekmiştir. Çünkü gerek demografi, gerekse de paleoantropoloji çalışma materyali olarak insan ve insan topluluklarını seçmişlerdir (Hoppa, 2002:9).

91 Bahsi geçen bölge: İlk Polonya Karpatlar ile Baltık kıyıları arasında Kuzey Avrupa Ovası'nın merkezinde Oder ve Vistül vadilerin de konumlanmıştır (Barford, 2001: 261).

92 Moravya: Bohemya ve Silezya ile birlikte Çek Cumhuriyeti içindeki tarihi bölgelerden biridir (britannica.com).

93 Bohemya: Çek Cumhuriyeti’nde bir bölge (Iggers, 1992: 18).

94 Niesse Nehri: Çek Cumhuriyeti'nden doğan ve Alman Zittau şehrinin 54 kilometre yakınından geçerek Polonya-Almanya sınırında son bulur (Allen, 1957: 17).

95 Paganizm: Kökenleri dünyanın kadim doğa dinlerine uzanan bir inanç biçimi ve bu dinlerin genel adidır (Jones\&Pennick, 1995: 1-10). 
ISSN-2199-353X

Online only at http://www.cahij.com/

Piast Hanedanlığının hâkimiyetine girebilmiş olan Polonya sınırlarına doğru gerçekleşen bir Alman ilerleyişiyle neticelenmişti (Halecki, 1980: 51).

Polonya ve Almanya ilk olarak I.Otto'nun taç giymesini takiben çarpışmışlar, yine aynı süreçte Çekleri bir araya getiren Premyšlid ${ }^{96}$ dükleri hem Katolikliği hem de Alman egemenliğini kabul etmişlerdi. 929 yılında cinayete kurban gitmesiyle Alman karşı 1tı bir harekete yol açsa da hiçbir şeyi değiştirmemesiyle Aziz Vaclav ${ }^{97}$ ' in saltanatı bu açıdan belirleyici olmuştu. Öte yandan Aziz Vaclav Bohemya ulusal egemenliğinin bir sembolü haline gelmişti. Erkek kardeşi ve halefi I.Boleslav Alman kralının feodal üstünlüğünü tanımak zorunda kalmış; böylelikle tüm ulusu 962 yılında Kutsal Roma İmparatorluğu'nun bir parçası durumuna gelmiştir. Söz konusu bağımlılık Polonya'nın vaziyeti ve iki batılı Slav gücü arasındaki işbirliği projesiyle bağlantılı olarak devam etmiştir (Halecki, 1980: 51).

\section{I. Mieszko’nun Hayatı Ve Siyasî Faaliyetleri}

Boleslav'ın vassallarından birinin Otto'ya bağlılığını sunmak -her ne kadar başarısız olsa da- istemesi sorun yaratmıştı. Fakat bu ihtilaf dostça çözümlenmiş, Boleslav Saksonlar üzerinde üstünlük sağlamıştı. 955 yılındaki Lechfeld Savaş ${ }^{98}$ 'na Otto ile birlikte katılan Boleslav sayesinde Macarlar yenilgiye uğratılmıştı. Böylelikle Boleslas sadece Moravya'yı değil, Silezya ${ }^{99}$, günümüz Slovakya toprakları ve Kraków’un da dâhil olduğu bölgeleri işgal etmişti. Bu duruma göre Bohemya, Büyük Moravya'nın varisi olacakmış gibi görünüyordu. Boleslav'ı etkileyen bu fikre I. Otto karşı çıkmamıştı. Çünkü her iki Bohemya dükü de yalnızca imparator olarak değil, Alman kralı ve Batı Hristiyan Birliği' nin (962'lideriden itibaren) olarak da ona bağlılık borçluydu (Dvornik, 1956: 109).

Bu dönemde ortaya çıkan bir diğer önemli unsur ise Polonya Dükü I.Mieszko (965-992 arası hükümdarlık yapmıştır) idi. Mieszko'nun geçmişine ilişkin kaynakların birçoğunda hemen hemen hiçbir bilgi bulunmazken, Polonya'nın XII.yüzyıl tarihçilerinden Gallus Anonymus 1115 yılında yazdığı 'Galli Anonymi cronicae et

\footnotetext{
96 Premyšlid: Çek hanedanlığı Dvornik, 1956: 105). Bohemya Dukalığı ve daha sonra Bohemya Krallığı ve Moravya Margaviate'in yanı sıra Polonya, Macaristan ve Avusturya'da hüküm süren bir Çek kraliyet hanedanıdır (Bažant-Bažantova-Starn, 2010: 31).

97 Aziz Vaclav: 921-935 yılları arası Bohemya dükü (Bažant\&Bažantova-Starn, 2010: 31 ).

98 Lechfeld Savaşı: (10 Ağustos 955) Macarlar ve Almanlar arasındaki bir dizi savaş. Almanların yenilgisi neticesinde Macarların Latin Avrupa'yı istilaları sona ermiştir (Bowlus, 2016: sy).

99 Silezya: Orta Avrupa' da tarihi bir bölgedir (britannica.com) Ayrıca daha geniş bilgi için bkz. Albert A. Scholz, Silesia Yesterday and Today.
} 
ISSN-2199-353X

Online only at http://www.cahij.com/

gesta ducum sive principum Polonorum' adlı eserinde bu konuya ayrintılı olarak değinmiştir. Mieszko'nun büyükbabası Piast'tan başlamak suretiyle kaleme aldığ hayat hikâyesi biraz efsanevi olmakla birlikte, dönemin gelenek ve göreneklerine de 1şık tutması açısından hayli ilginçtir:

“Gniezno'da (Slav dilinde 'kuş yuvası' manasına gelmektedir) Popiel ${ }^{100}$ isimli bir dük yaşamaktaymış. Pagan adetlerine göre oğlunun saçlarını kestirme ${ }^{101}$ zamanı geldiğinde görkemli bir ziyafet hazırlatmış; asiller ve dostlarından oluşan kalabalık bir grubu bu ziyafete davet etmişti. Tam da aynı gün kente iki yabancı gelmiş ancak bu yabancılar yemeğe çağırılmadıkları gibi, şehirden de uzaklaştırılmışlardı (Anonymus, 2003: 16). Fakat o gün tıpkı Popiel gibi, oğulları için benzer seremoniyi gerçekleştirmek adına hazırlık yapan biri daha vardı. Fakir ama cömert olan ve varoş bölgede yaşamını sürdüren bu adam şehirden uzaklaştırılan yabancılara kapısını açmıştı. Evde Chościsko'nun oğlu Pazt ${ }^{102}$ ve eşi Rzepka ${ }^{103}$ bulunmaktaydı (Anonymus, 2003: 19). İki yabanc1, erkek çocuğun saçlarını kesmiş ve yaşananlara kutsiyet atfederek ona 'Siemovit ${ }^{104}$ ' adını vermişlerdi (Anonymus, 2003: 23). Büyüyen Siemovit gittikçe güçlenmiş ve Polonya dükü olmuştu. Pumpil ve tüm soyu için krallığ1 kurtarmıştır. Aktarılanlara göre Pumpil krallıktan sürülmüştü. Şehir fareler tarafından kuşatılmışt1, müritleri her ne kadar onu bir adaya götürmüş olsalar da fareler onu izlemiş ve ölümüne neden olmuşlard1 (Anonymus, 2003: 25). Bahsi geçen olay1 Anonymus bu şekilde aktarırken, Norman Davies ise Popiel'in Kruszwica ${ }^{105}$ ' daki

100 Popiel: Bu isimle birlikte 'Pumpil' de kullanılmaktadır. Hanedanlığı klasik kökene dayandırma çabasındaki Kadłubek Romalı Pampilius ile bağlantı kurmak istemiştir, bkz. Magistri Vincentii dicti Kadłubek Chronica Polonorum, s. 23. Lakabı ise 'hain'dir (Davies, 2005: 52).

${ }^{101}$ Bir tören olan bu gelenek tanrıların saç şekilleriyle bağlantılıdır (Anonymus, 2003: 16).

102 Pazt: Mieszko'nun büyükbabası. Kullanılan bu isim pek çok spikülasyona sebebiyet vermiştir. Tarihçilerin çoğu bunun Piast'1 temsil ettiği görüşündedir. Ortaçağ kaynaklarında Piast ismine rastlanmazken, daha ziyade XVI.yüzyıldan itibaren kaleme alınan eserlerde kullanıldığı görülmüştür (Anonym, 2003: 19).

103 Rzepka: Bir takma ad görünümündeki bu ismin kökeni 'rzepa'dan yani 'turp' kelimesinden gelmektedir (Anonymus, 2003: 19).

104 Siemovit: Muhtemelen 845 yılında dünyaya gelmiş, 900'de vefat etmiştir. İsmin etimolojisi tartışmalıdır. İsmin ilk bölümü Eski Slavca' da 'simuja' (Rusça'da 'scmia) 'yani hizmetkârlar, köleler, aile anlamına gelirken; '-vit' ise lider, asil ya da aile reisi şeklinde tercüme edilmiştir, bkz. Aleksander Brückner, Słownik Etimologiczny Języka Polskiego, (Etimological Dictionary of the Polish Language), s. 489.

105 Kruszwica: VI.yüzyılda Polonya’nın merkezinde kurulmuş olan tarihi bir kasabadır (Bousfield, 2009: 574). 
zindanda fareler tarafindan öldürüldügü ve ardından 500 yıl süren Piast hanedanlığının kurulduğunu belirtmektedir (Davies, 2005: 52). Ölen Siemovit' in yerine oğlu Leszek geçmişti. Onun ardından da tıpkı baba ve dedesi gibi hatta onlardan çok daha asil ve onurlu Siemomysł (Siemovit) gelmişti (Anonym, 2003: 23). İşte I.Mieszko, Siemomysł' $n$ oğluydu. Yedi yaşına kadar gözleri görmeyen Mieszko gibi Polonya'nın da o zamana dek kör olduğu benzetmesi yapılmakta ve de kehanete göre Polonya, Mieszko'nun dünyaya gelişiyle aydınlanacaktı. Zira Polonya Mieszko'dan önce Allah'a inancı olmayan pagan bir toplumdu, Mieszko ile birlikte Hristiyanlığı seçerek bir dini inanca sahip olmuştu (Anonym, 2003: 27)”.

Ünlü tarihçiler Merseburglu Thietmar ${ }^{106}$ ve Arap asıllı yazar İbn Yakub ${ }^{107}$ ' a göre Mieszko çok zeki bir yöneticiydi. Paralı askerlerden oluşan 3 bin kişilik bir orduya sahipti $^{108}$. 'Polane' adı verilen ve merkezi Gniezno (Gnesen) olan bir Slav federasyonunun lideriydi (Dvornik, 1956: 110). Prag’da bulunan İbrahim İbn Yakub ayrıca 'Kuzeyin Prensi' ${ }^{109}$ (Strzelczyk, 2016: 54) olarak nitelendirdiği Mieszko'nun, Slav halkının büyük çoğunluğu tarafından kabul gördüğü ifade etmiştir. Ülkede toplanan tüm vergilerin Mieszko'ya ait olduğu ve tamamını da askerleri için kullandığını belirtmiş; maiyetindekilerin onun gücünden etkilenmesinin I.Otto'nun dikkatinden de kaçmadığını sözlerine eklemişti (Barford, 2001: 262).

X.yüzyıl ortalarında böylesi güçlü bir prensin Orta Avrupa' da siyaset sahnesine çıkışı pek çok tarihçiyi hayrete düşürmüş, oluşan bu sıkıntıyı çözmek adına da bir teori geliştirmişlerdi. Söz konusu teori uyarınca Mieszko, Oder ve Vistül boyunca yaşayan Slav halkı egemenliği altına almak isteyen İskandinavyalı bir Viking idi. Ancak buna, yani Piast' in Slav kökenli olmadığına dair hiçbir kanıt bulunmamaktadır. Şayet Mieszko'nun en azından İ.Ö.500 yılından itibaren bu bölgede yaşamakta olan Slav halk üzerinde egemenlik kurduğu göz önünde bulundurulursa X.yüzyılda bu bölgelerdeki güçlü konfederasyonun görünümü gizemli olmaktan çıkmaktadır. Mieszko'nun

${ }^{106}$ Merseburglu Thietmar (975-1018): 1009 yllından ölümüne kadar Merseburg Prensi - Piskoposu Thietmar, Alman krallarının ve Osmanlı Hanedanlığının Kutsal Roma imparatorlarının hükümdarlığını kaydetmiş olan önemli bir kronikçidir (Warner, 2001: 2-64).

107 İbrahim İbn Yakub: X yüzyılda yaşamış Yahudi diplomat ve tüccar (Curta, 2019: 397). Daha geniş bilgi için ayrıca bkz. Andrzej Pleszczyński, The Birth of a Stereotype, Polish Rulers and Their Country in German Writtings c. 1000 A.D., 14-24 s.

108 Adam Zamoyski de 'The Polish Way' adlı eserinde aynı konuya değinmiş ancak İbrahim İbn Yakub’un Mieszko'nun ordusunun 300 bin atlı askerden oluştuğunu ifade etmiş̧tir (Zamoyski, 1987: $10)$.

${ }^{109}$ Mieszko’yu 'Kuzeyin Prensi’ olarak nitelendiren sadece İbrahim İbn Yakub değildi. Dönemin diğer, hatta daha eski kaynaklarında da bu benzetmeye rastlanmaktadır (Strzelczyk, 2016: 54). 
ISSN-2199-353X

Online only at http://www.cahij.com/

kurduğu oluşum Slav hanedanlığının liderliğinde evrilmiştir. Evrimin süreci hakkında ne yazık ki hiçbir bilginin var olmamasının nedeni ise o tarihlerde yaşananları gelecek nesiller için kaydedecek bir tarihçi bulunmamasıydı (Dvornik, 1956: 110). Mieszko'nun yaptıkları kayıt altına alınmaya başlandığında o, Pomeranya Slavlarını hanedanlığına katmaktaydı. Almanları gözü ise bu bölgede, özellikle Stettin'de (Sczeczin) $)^{110}$ idi. Mieszko gayet ak1llıca bir plan yaparak bu konuyla ilgili olarak 963 yılında Gero ${ }^{111}$ ile ilişki kurmuştu. Fethettiği Pomeranya'yı Sczeczyn ile birlikte elinde tutacak, ancak imparatorluğun bir tımarı haline getirecekti (Dvornik, 1956: 110). Bu zekice planı sayesinde Almanların müdahalesi olmaksızın Batı Pomeranya'nın fethini tamamlayabilecekti. Fakat Mieszko'nun ne ülkesini tımar yaptığı, ne de buna ihtiyaç duyduğuna dair herhangi bir kanıt bulunmamaktadır (Dvornik, 1956: 112).

En başından itibaren Polonya, Alman İmparatorluğunun dişında kalmayı tercih etmişti. Ancak Otto'nun Magdeburg, Polabian ve Baltık Slavlarının Hristiyanlaştırılmasına dair planı Mieszko'nun bir başka tehlikeyle karşılaşmasına yol açmıştı. Mieszko, halkının Hristiyanlaşmasının gerekli olduğunu görmüştü. Ayrıca Hristiyanlığın, siyasi ve kültürel anlamda Bohemya'ya sağladığı faydaların da farkındaydı. Hristiyanlığ zamanda kendisine yararlı bir müttefik edinebilirdi. Alman baskısından uzak durabilmek ve ülkesine olabilecek muhtemel Alman müdahalelerini önleyebilmek adına Dük Mieszko 965 yılında, I. Otto'nun da onayıyla Bohemya dükünün kızıyla evlendi. Ertesi sene de gönüllü olarak halkıyla birlikte Hristiyanlığı seçti; bu sebeple vaftiz olan Mieszko, adının barbarlara ait olarak addedilmesinden dolayı 'Mieczysław' adını aldı (Długosz, 1997: 1). Böylelikle Polonya Dukalığı Hristiyan Birliği’ nin resmen bir parçası haline gelmiş (Zamoyski, 1987: 10) ve I. Boleslas ona ilk Hristiyan misyonerlerini göndermişti (Dvornik, 1956: 112). Aynı konuya değinen XIV. yüzyıl tarihçisi Jan Długosz' a göre 965 yılı Polonya'da Hristiyan lobisinin oldukça güçlü olduğu bir yıl idi ve Mieszko’nun pagan inancindan vazgeçerek Hristiyanlığı seçmesi için Bohemya'ya Boleslav'a elçiler gönderilmişti. Elçilerin amaciysa Boleslav'1,

${ }^{110}$ Stettin (Sczeczin): Odra nehri üzerinde yer alan bir Slav kentidir. Bir kale ve liman şehri olan Stettin, XI. ve XII.yüzyıllarda önemli bir ticaret merkezi olmuştur (Lerski, 1996: 582).

111 Gero: Acımasız yöntemleriyle Alman sırlarını Niesse ve Bober Nehirlerine kadar genişleten konttur. Slavların hatırasında uzun süre yer eden Gero yatıklarıyla Alman kahramanlık destanı 'Nibelungenlied' de yer almıştır (Dvornik, 1956: 108). 
ISSN-2199-353X

Online only at http://www.cahij.com/

kızkardeşi Dubravka ${ }^{112}$ 'yı Mieszko ile evlendirmesine ikna edebilmekti. Böylelikle Mieszko Hristiyan olacaktı (Długosz, 1997: 1).

Ancak Mieszko'nun hiç de itaatkâr bir vaftiz çocuğunu oynamaya niyeti yoktu. İmparatorlukla arası bozulsa bile amaçlarını sürdürdü. Bunlardan birisi Baltık kıyılarında mümkün olduğunda geniş bir egemenliğe sahip olmaktı. Pomeranya'yı istila etti fakat kısa bir süre sonra Alman İmparatorluğu adına bölgeyi fethetmeye gelen kuzey sınırı uçbeyiyle karşılaşmıştı. 972'de onu bertaraf ederek 976'da Oder' ulaşmıştı. Bunun üzerine II. Otto'dan yardım isteyen uçbeyi nedeniyle Polonya'ya büyük bir sefer düzenlemişti. Ancak Mieszko 979 yılında Almanları tekrar bozguna uğrattı ve Pomeranya'nın tartışmasız hâkimi olmuştur. Zaferlerine Polonya'nın en önemli liman kenti olan Gdańsk’i ele geçirerek devam etmiştir (Zamoyski, 1987: 12).

Polonya'nın ilk Hristiyan yöneticisi imparatorluğun siyasi etkisinden uzak kalabilmek için topraklarının bir bölümünü vergi (haraç) olarak vermeyi kabul etmiştir. I.Mieszko 968' de Poznań ${ }^{113}$ ' da kurulan ve doğrudan Vatikan'a bağlı olan ilk Polonya Piskoposluğunu istemiştir (Halecki, 1980: 52). Tam da bu süreçte Roma Kralı ve Saksonya Dükü I. Otto pek çok Sakson bölgesini putperestlikten vazgeçmeye, Hristiyanlığ 1 seçmeye zorlamaktaydı. Hatta bu sebeple 973 yılında Magdeburg' da bir papalık kurulmuş, Otto öldüğünde de buradaki St. Maurice Kilisesi'ne defnedilmişti (Długosz, 1997: 3).

Bohemya ve Polonya dükleri 966 yılında Papa XIII.John’a (965-972) ülkelerinde piskoposluklar kurma talebinde bulunmuşlardı. I. Otto bu öneriye olumlu yaklaşmış, karş 1 çıkmamıştı. Bunun neticesi olarak Poznań'da (Posen) 968'de, Magdeburg yerine Roma'ya bağlı olan Leh Piskoposluğu teşkil edilmişti. Prag' daki piskoposluk ise ancak 973'te kurulabilmişti. Buna da karşı çıkmayan Otto, 967' de babasına haleflik eden II.Boleslav üzerinde daha fazla etki kazanabilmek amacıyla biri Prag'da, diğeri ise Moravya'da olmak üzere kendi çıkarına çalışan iki piskoposluk kurmuştu. Ayrıca babasının politikalarını devam ettirebilmek için de Çek Piskoposluğunu Salzburg ${ }^{114}$

112 'Dubravka' ya da Lehçe'de 'Dąbrówka' Bohemyalı Hristiyan bir kadındı (Anonym, 2003: 29). Farklı kaynaklarda bu isim ayrıca Dubrouka, Dubrovka, Dambrovca, Dubrowka, Dambrouca şekillerinde kullanılmıştır (Strzelczyk, 2016: 112).

113 Poznań: Warta Nehri kıyısında, Polonya'nın orta batı kesiminde bulunan bir şehirdir (Lerski, 1996: 472).

114 Salzburg: Avusturya'nın orta-kuzey kesiminde yerleşim bölgesi olup dördüncü büyük kentidir (Salisbury, 2007: 4). 
yerine Bavyera $^{115}$ ' ya Mainz ${ }^{116}$ ' a bağlamıștı (Dvornik, 1956: 112). Bu süreçte doğuda Mieszko tarafından çok önemli değişiklikler gerçekleşmekteydi. Pomeranlar'ın yanı sira Oder ve Vistül'deki halk üzerinde durumunu güçlendiren Mieszko Beyaz Hırvatistan'ın Slav halkını ilhak etme çabasındaydı. II. Boleslas babasına göre fazla başarılı sayılmazdı, onun kaçırdığı fırsatları ise Mieszko değerlendirmiş, Silezya ve Kraków’u ülke topraklarına dâhil etmiş̧ti (Dvornik, 1956: 113).

Bohemyalı II.Boles lav ile 967 y ılında babasının yerini alan Polonyalı I.Mieszko, I. ve II.Otto'nun ölümünün ardından Almanya'nın içişlerine müdahale etmeye başlamışlardı. Birkaç tane Alman uçbeyi ile ilişki kuran I. Mieszko Çek asıllı eşinin vefatından sonra bu uçbeylerinin kızlarından biriyle evlenmişti. Ancak ne Bohemya, ne de Polonya diğer batılı Slav kabilelerine Almanya ile olan mücadelelerinde destek olmamışlardı. Ortaklaşa hareket edemeyişlerinin altında ise koordinasyon yetersizliğinin beraberinde bölgesel anlaşmazlıklar yatmaktaydı. I.Mieszko'nun saltanatının son döneminde Bohemya'dan hangi toprakları almış olduğu belirsizdir. Ancak bu belirsizliğe karşın söz konusu toprakların Kraków ${ }^{117}$ ve Çeklerin geçici olarak işgal ettikleri Küçük (Güney) Polonya (Małopolska) ${ }^{118}$ olduğu bilinmektedir. I.Mieszko bu toprakların doğu bölümünü (günümüzde Doğu Galiçya olarak adlandırılmaktadır) 981 yılında Kievli Prens Vladimir'e vermek zorunda kalmıştır. Zaten onun asıl elde etmek istediği topraklar Gniezno ${ }^{119}$ ve Poznań bölgelerinin merkezi konumundaki Büyük Polonya ${ }^{120}$ idi. Böylelikle Baltık kıyılarına ulaşarak Pomeranlar ile yakınlaşıp Polonya ile birlik kuracak ve İskandinav dünyası ile iletişim sağlayacaktı (Halecki, 1980: 52).

Otto'nun Magdeburg'u tüm Doğu Slavlarının kutsal merkezi haline getirme planı böylelikle kısmen de olsa gerçekleşmişti. İlerleyen dönemlerde Elbe ve Oder

\footnotetext{
${ }^{115}$ Bavyera: Almanya’nın güneydoğusunda bir eyalet (Merkl, 2012: 9-10).

116 Mainz: Almanya'da Ren Nehri kıyısında bir kent (britannica.com).

${ }^{117}$ Kraków: Polonya'nın en eski ve büyük üç şehrinden biridir. Tarihi şehir Vistül Irmağı'nın Wawel Tepesi'nin yağında Küçük Polonya'nın güneyinde yer almaktadır. Küçük Polonya Voyvodasının da 1999 yılından bu yana başkentidir (Lerski, 1996: 89,90). Daha ayrıntılı bilgi için ayrıca bkz. Jan Dąbrowski, Kraków..

${ }^{118}$ Małopolska (Küçük Polonya): Merkezi Kraków'dur. Silesia, Mazova, Podlasie, Ukrayna ve Slovakya arasında, Polonya'nın güneyinde yer alan tarihi kenttir (Lerski, 1996: 309).

119 Gniezno: Polonya'nın orta batı kesiminde bulunan bir şehirdir (Ring\&Watson\&Schellinger, 2013_ 309).

120 Wielkopolska (Büyük Polonya): Merkezi Poznańdır Warta nehri kıyısında Pomerania ve Silesia arasında yer alan kenttir(Lerski, 1996: 177).
} 
ISSN-2199-353X

Online only at http://www.cahij.com/

bölgeleri aras ındaki gelişmeler nedeniyle Otto'nun bahsi geçen kurumları en az iki yüz yıl boyunca daha faaliyete geçirilememişti. 983 yılında Elbe'ye Otto'nun Calabria $^{121}$ ' da Araplara yenilerek öldüğü haberlerinin ulaşması Elbe, Oder ve Baltık bölgelerindeki Slavların Almanlara karşı ayaklanmasına neden olmuştu. Bu kanlı mücadelenin neticesinde Almanlar güçsüz duruma düşmüş, Slavları Hristiyanlaştırma görevi de genç imparator III. Otto’ya kalmıştı (Dvornik, 1956: 113). I. Mieszko yaşamının sonlarına doğru ülkesini Papalığın otoritesi altına sokmuştu. Böylelikle, Oder'in ağzından Baltık Prusya ve Kievan Rus sınırına değin uzanan Polonya'nın, I. Mieszko'nun muhtemelen kraliyet tacını kazanarak desteklemek istediği en iyi özgürlük garantisiydi (Halecki, 1980: 52).

X.yüzyılın sonu itibarıyla Doğu Avrupa'da, ilerleyen süreçte diğer Slav topraklarını da kapsayacak olan bir Slav devleti kurulmuştu. Fakat İtalya ile ilgili sorunlarla ilgilenen II.Otto bu sürece dâhil olamamıştı. Papa'nın koruması ve Avrupa' daki ruhani güce sahip olmak isteyen Mieszko ise 992 yılındaki ölümünden evvel Szeczyn'den Gdańsk'e, Gniezno’dan Kraków’a dek tüm krallığını Papalığın hizmetine sunmuştu ${ }^{122}$. Mieszko'nun bu akıllıca hamlesi yüzyıllar boyunca Polonya tarafından takip edilmişti (Dvornik, 1956: 113). Polonya'nın bu önlenemez yükselişinin sonuçları Bohemya'da etkisini göstermişti. Ülke, Premyšlid ve Slavnik olmak üzere iki dukalığa ayrılmıştı. Barış içerisinde yürütülen Bohemya-Polonya işbirliği Polonya'nın Silezya ve Kraków’u ele geçirmesiyle sekteye uğramıştı. II.Boleslav’ in söz konusu bölgeleri geri alma isteğine Slavnik Dükü Sobeslav karş1 çıkmış; ancak buna rağmen Lehlere saldıran Boleslav yenik düşmüştür (Dvornik, 1956: 114). Libice ${ }^{123}$ de Bohemya tarafından 7 bin kişi katledilmiş, şehir yakılıp yıkılmıştır (Długosz, 1997: 8). Yaşananların ardından 995 yılında ${ }^{124}$ Slavniklere saldıran II. Boleslav'ın kadın, çocuk demeden gerçekleştirdiği katliam bu sonucunda Sobeslav o dönemim yeni Polonya Dükü Bolesław Chroby’ya sığınmıştır. Bu suretle her ikisinin de ortak amaçları Prag'dan intikam alabilmek olmuştu (Dvornik, 1956: 115).

\footnotetext{
${ }^{121}$ Calabria: Güney İtalya’da bir bölgedir (Colafemmina, 2012: 1).

122 Vatikan Arşivi'nde yer alan 'Schi-gnesne' adlı belgenin ilk iki kelimesi olan 'Dagome ludex' onun tüm topraklarını Papalığa emanet ederek, hizmetine sunduğunu göstermektedir. Ülkenin sınırlarını belirleyen bu belge adından da anlaşılabileceği üzere ülkenin başkent Gniezno'ya atıfta bulunmaktadır (Barford, 2001: 263).

123 Libice: Çek Cumhuriyeti'nin Orta Bohemya bölgesinde bir köydür. Cidina ve Elbe nehirlerinin birleştiği yerde bulunan Bohemya'nın en eski yerleşim alanlarından biridir (britannica.com).

${ }^{124}$ Długosz bu tarihi 993 olarak vermektedir (Długosz, 1997: 8).
} 
I. Mieszko ve Bolesław dönemlerinde, tüm diğer Slav Birliği ülkelerinin devlet oluşumu esnasında yaşadığı sosyo-ekonomik açıdan bir değişim sürecine girmişti. En önemli değişim maddesel kültürün çeşitlendirilmesindeki yeni sosyal sistem ve benzeri gelişmelerdi. Arkeolojik bulgular neticesinde o dönem sosyal bir katmanlaşma yaşandığı ve nüfusun çarpıcı düzeyde artışı göze çarpmaktadır (X.yüzyılda Polonya' da 250 bin kilometrekarelik alanda yaklaşık olarak 125 milyon insan yaşadığı tahmin edilmektedir). Yine arkeolojik kanıtlar zanaat alanındaki uzmanlaşmanın sonucunda X.yüzyıl ortalarında bazı teknolojik gelişmeler yaşandığını da ortaya koymaktadır. Mutfak araç ve gereçleri, ayakkabı imalatı, deri, kemik ve boynuz işçiliğindeki artış bunu doğrular niteliktedir (The World of the Slavs, 2013: 265).

Sınırlarını doğuya doğru genişletmek isteyen Danimarkalılar ile oldukça iyi ilişskiler kuran Mieszko kızı Swiętosława’yı İsveç ve Danimarka Kralı Eric ile evlendirmişti. Kızı, Eric'in ölümünden sonra ikinci kez Danimarka kralı olan Swein Forkbeard'le evlenmişti. Bu evliliğinden, 1014 yılında Polonya'yı ziyaretinde üç yüz atlı asker toplayarak eski krallığı olan İngiltere Krallı̆̆ı'nı fetheden 'Canute ${ }^{125}$, dünyaya gelmişti (Zamoyski, 1987: 12). I.Mieszko'nun bu başarıları 992 yılında yerine geçen oğlu Bolesław Chroby (Cesur Bolesław) tarafından sürdürülmüştür. Bolesław’ın amacı da tıpkı babası gibi ülkesinin, tam an lamıyla özgür olmasının yan sıra Orta Doğu Avrupa'nın lideri durumuna gelebilmesiydi (Halecki, 1980: 53). Polonya, tarihinde oldukça önemli bir şahsiyet olan I. Mieszko ile birlikte izalasyon sürecini sona erdirmiş, diş dünyayla hatta güçlü Almanya'yla ilişki kurmaya karar vermiştir (Zamoyski, 1987: 10).

\section{Sonuç}

Aynı kökenden gelen ve kayıtlı tarihleri VI.yüzyıldan itibaren olan Slavlar, özellikle IX.yüzyılın sonlarına doğru Bizans İmparatorluğu'nun dış politikasında önemli bir yer tutmuşlardır. Bu nedenle Slavların gerek kültür, gerekse günlük yaşamları Bizans geleneklerinden fazlas ıyla etkilenmiştir. Slavların ortak kökene sahip olduklarını sadece arkeolojik, paleodemografik, antropolojik ve tarihi araştırmalar değil, dilbilim çalışmaları sonucu elde edilen veriler de destekler niteliktedir. Zira Slav dilleri yazılışlarındaki farlılıklara rağmen fonetik açıdan incelendiğinde sesteş birçok kelime ihtiva ettikleri görülmektedir. Hatta bunların büyük bir kısmı Polonya dilinde halen kullanılmaktadır. Yukarıda bahsettiğimiz, Slavlar üzerinde Bizans etkilerinin görülmeye başladığı süreç, geçmişinde kuruluşuna dair pek çok efsane barındıran Polonya'nın da oluşumunun başlangıcıdır. Leh hanedanlığının kurucusu I.Mieszko

125 Canute (990-1035): İngiltere, Norveç ve Danimarka kralıdır. Daha geniş bilgi için bkz. Anna Kowalska Pietrzak "History of Poland During the Middle Ages, s. 64. 
ISSN-2199-353X

Online only at http://www.cahij.com/

döneminde, içe kapanık bir toplum olan Polonya halkı onun sayesinde diş dünyaya açılmış, en ciddi tehdit konumundaki Almanya ile dahi baş edebilecek duruma gelmiştir. Bu doğrultuda 966 yılı başta Polonya, ardından ise Avrupa için önemli bir tarihtir. I.Mieszko söz konusu tarihte Almanya'nın dini olan Hristiyanlığı, dolayısıyla Roma'yı seçerek hem bir müttefik kazanmış, hem de Batı Hristiyan Birliği'ne dâhil olmuştur. I.Mieszko'nun yaptı̆̆ı bu tercih Polonya'nın Avrupa'ya yakınlaşmasıyla geleceğini şekillendiren en önemli unsur olmuştur.

\section{KAYNAKÇA}

-Abulafia, David-Franklin, Michael\&Rubin, Miri (1992), Church and City 1000-1500, Essays in Honour of Christopher Brooke, Cambridge University Press, United Kingdom, United States of America.

-Akçura, Yusuf(2016), Târih-i Siyâsi, 1926-1927-1928 Ders Notları, Ötüken Neşriyat, İstanbul.

-Allen, Debro J. (1957), The Oder-Niesse Line, The United States, Poland and Germany in the Cold War, Nr. 103, Praeger, London.

-Antonowicz-Baner, Luczyna\&Dubiński, Aleksander (1983), Słownik Turecko-Polski i Polsko-Turecki, Wiedza Powszechna, Warszawa.

-Baldwin, Edward (1806), The Pantheon; or Ancient History of the Gods of Greece and Rome, Thomas Hodgkins Print, Oxford.

-Barford, P. M. (2001), The Early Slavs, Culture and Society in Early Medieval Eastern Europe, Cornell University Press, Ithaca, New York.

-Barnish, Sam J.\&Marazzi, Frderico (2007), The Ostrogots from the Migration Period to the Sixth Century, An Ethnographic Perspective, The Boydell Press, San Marino, United States of America.

-Bažant, Jan-Bažantova\&Starn, Francis (2010), The Czech Reader; History, Culture, Politics, Duke University Press, Durham and London.

-Beattie, Willam (1844), The Danube, Its History, Scenery, and Topography, George Virtue, Ivy Lane, London.

-Bevan, W. L. (1871), The Students' Manual of Ancient Geography, William Cloves and Sons, London.

-Bjerg, Line\&Lind H. \&Sindbaek, Soren M. (2013), From Goths to Varangians: Communivation and Cultural Exchange between the Baltic and the Black Sea, Aarhus University Press, England. 
ISSN-2199-353X

Online only at http://www.cahij.com/

-Bousfield, Jonathan (2009), The Rough Guide to Poland, Rough Guides.

-Bowlus, Charles R. (2016), The Battle of Lechfeld and Its Aftermath, August 955: The End of the Age of Migrations in the Latin West, Routledge, London, New York.

-Brückner, Aleksander (1985), Słownik Etimologiczny Języka Polskiego, Wiedza Powszecha, Warsaw.

-Burns, Thomas (1991), A History of the Ostrogoths, Indiana University Press, Bloomington and Indianapolis.

-Caferoğlu, Ahmet (1933), Azerbaycan Yurt Bilgisi, 2.Cilt, Bürhaneddin Matbaas1, İstanbul.

-Cameron, Averil (1985), Procopius and the Sixth Century, Routledge, London, New York.

-Carter, F. W. (1994), Trade and Urban Development in Poland, An Economic Geography of Cracow, from Its Origins to 1995, Cambridge university Press, United Kingdom.

-Clark, Charles Upson (1927), Bessarabia: Russia and Roumania on the Black Sea, Dodd, Mead.

-Colafemmina, Cesare (2012), The Jews in Calabria, A Documentary History of the Jews in Italy XXXIII, The Goren-Goldstein Diaspora Research Center, Tel Aviv University, Brill, Leiden, Boston.

-Cole, Jeffrey E. (2011), Ethnic Groups of Europe, Greenwood Publishing Group, ABC CLIO, England.

-Curta, Florin (2001), The Making of the Slavs, History and Archaelogy of the Lower Danube Region, c. 500-700, Cambridge University Press.

Leiden, Boston.

(2019), Eastern Europe in the Middle Ages (500-1300), Vol.1, Brill,

-Cvijanović, Irena (2013), "The Typology of Early Medieval Settlements in Bohemia, Poland and Russia”, pp. 289-344.

-Davies, Norman (2005), God's Playground, A History of Poland, Vol.1 The Origins to 1795 , Columbia University Press, New York.

-Dąbrowski, Jan (1965), Kraków, Jego Dzieje i Sztuka

-Derow,Peter\&Parker, Robert (2003), Herodotus and His World, Oxford University Press, (Essays From a Conference in Memory of George Forrest), New York. 
-Długosz, Jan (1997), Annales seu Cronicae incliti regni Poloniae (The Annals of Jan Długosz), Redwood Books, United Kingdom.

-Dvornik, Francis (1956), The Slavs-Their Early History and Civilization, American Academy of Arts and Sciences, Boston.

-Encyclopedia of Indo-European Culture (1997), Ed. J. P. Mallory-D. Q. Adams, Fitzroy Dearburn Publishers, London, Chicago.

-Farrugia, Edward G. (1988), Christianity Among the Slavs: The Heritage of Saint Cyril and Methodius; Acts of the International Congress Held on the Eleventh Centenary of the Death of st. Methodius, Rome, Oct, 8-15-1985.

-Földvary, G. Z. (1988), Geology of the Carpathian Region, World Scientific Publishing, Singapore.

-Gallus, Anonymus (2003), Galli Anonymi cronicae et gesta ducum sive principum Polonorum (Anonima tzw. Galla Kronika czyli dzieje Książąt i włodców polskich ed.), Gesta principum Polonorum, The Deeds of the Princes of the Poles, Vol.3, Cenral European Press, Budapest, New York.

-Gibbon, Edward (1854), The History of the Decline and Fall of the Roman Empire, John Murray, Vol. 5, London.

-Halecki Oskar (1980), Borderlands of Western Civilization, A History of East Central Europe, Ed. Andrew L. Simon, Simon Publications, La Vergne.

-Hamm, Michael F. (1993), Kiev, A Portrait, 1800-1917, Princeton University Press, New Jersey.

-Hinds, Kathryn (2010), Barbarians! Ancient Celts, Early Germans, Goths, Huns, Scythians and Sarmatians, Vikings, Marshall Cavendish, New York.

-Holbach, Maude (2007), Dalmatia, The Land Where East Meets West, Cosimo Classics, New York.

-Hoppa, Robert D. \& Vaupel, James W. (2002), Paleodemography, Age Distributions from Skeletal Samples, Cambridge University Press, New York.

-Hurbanič, Martin (2019), The Avar Siege of Constantinople in 626, Palgrave Macmillan, Switzerland.

-Iggers, Wilma Abeles (1992), The Jews of Bohemia and Moravia, A Historical Reader, Wayne State University Press, Detroit.

-Jones, Gwyn (1984), A History of the Vikings, $2^{\text {nd }}$ Edition, Oxford University Press. 
ISSN-2199-353X

Online only at http://www.cahij.com/

-Jones, Prudence\&Pennick, Nigel (1995), A History of Pagan Europe, Routledge, London, New York.

-De Jong, Albert (1997), Traditions of the Magi, Zoroastrianium in Greek\&Latin Literature, Brill, Leiden, New York, Köln.

-Kiss, Andrea (2019), Floods and Long-Term Water-Level Changes in Medieval Hungary, Springer, Austria.

-Kraitsir, Charles V. (1837), The Poles in the United States of America, Kinderlen and Stollmeyra, Philadelphia.

-Kurat, Akdes Nimet (1987), Rusya Tarihi, Başlangıçtan 1917’ye Kadar, Atatürk Kültür, Dil ve Tarih Yüksek Kurumu Yayınları, XIII. Dizi, Sayı 17, Ankara.

-Kuzio, Taras (2008), Ukranian political Update, Frishberg\&Partners, Attorneys at Law.

-Lagutov, Viktor (2010), Environmental Security in Watersheds: The Sea of Azov, The NATO Science for Peace and Security Program, Springer, Russia.

-Lemerle, Paul (2011), Bizans Tarihi, İletişim Yayınları, Çev: Galip Üstün, İstanbul.

-Lerski, George J., (1996), Historical Dictionary of Poland (966-1945), Ed. Piotr Wróbel ve Richard J. Kozicki, Greenwood Publishing Group, Westport, Connecticut.

-Lewinski-Corwin, Edward H. (1917), The Political History of Poland, The Polish Book Importing Company, New York.

-Lichtensztul, Joseph (1944), "The White Ruthenian Problem in Eastern Europe", Bulletin of the Polish Institute of Arts and Science in America, Vol. 2, pp. 1170-1197.

-Lukowski, Jerzy-Zaeadzki, Hubert (2006), A Concise History of Poland, Cambridge University Press, New York.

-Magistri Vincentii dieti Kadłubek Chronica Polonorum (1994), ed. Marianus Plezia.

-Mangi, H. O. (2016), “Tide Management in the Elbe River and Changes in Ecosystem Services", Hindawi Publishing Corporation, Advances in Ecology, pp. 1-13.

-Mc Martin, Dena W.-Gilles, Jon A.-Von Tümling, Wolf-Headley, John V. (2013), "Observations of Resin Acid Distribution in the River Saale, Germany", Canadian Water Resorces Journal, Canada.

-Mazzocco, Angelo (1993), Linguistic Theories in Dante and the Humanists, Studies of Language and Intellectual History in Late Medieval and Early Renaissance Italy, Vol. 38, E. J. Brill, Leiden, New York, Köln. 
ISSN-2199-353X

Online only at http://www.cahij.com/

-Merkl, Peter H. (2012), Small Town\&Village in Bavaria, The Passing of All Way of Life, Berghahn Books, United States of America.

-Mountain, Harry (1997), The Celtic Encyclopedia, Vol.1, Universal-Publishers.com, Portugal.

-Olander, Thomas (1974), Proto-Slavic Inflectional Morphology, Brill, Leiden, Boston.

-Özdemir, Mehmet Nadir (2011), “ ‘Sakâlibe’ Unsuru ce İslâm Dünyasına Girişi-İslâm Kaynaklarına Göre-, Çukurova Üniversitesi İlahiyat Fakültesi Dergisi 11(1), ss. 89107.

-Penn, James-Allen, Larry (2001), Rivers of the World, A Social, Geographical, and Environmental Sourcebook, ABC CLIO, California, England.

-Pietrzak, Anna Kowalska (2015), "History of Poland During the Middle Ages", Institute of History, University of Łódź, pp. 61-93.

Institute of History of Lodz, pp. 61-93.

(ty), "History of Poland During the Middle Ages",

-Plesycyzński, Andrzej (2011), The Birth of a Stereotype, Polish Rulers and Their Country in German Writtings c. 1000 A.D., Vol. 15, Ed: Florin Curta, BRILL, Leiden, Boston.

-Rappoport, Angelo S. (1915), Of Poland, From Ancient Times to the Insurrection of 1864; Together with a Brief Account of Its Political Life, Language, and Literature, The Complete Press, London.

-Rice, David Talbot (2008), Bizans Tarihi, (Çev. Abdulhalik Bakır, Pınar Ülgen), Ortaçağ Tarih ve Medeniyetine Dair Çeviriler II, Ankara, s. 641-655.

-Roberts, J. M. (2015), Avrupa Tarihi, İnkılâp Kitabevi, İstanbul.

-Ring, Trudy\&Watson, Noelle\&Schellinger, Paul (2013), Northern Europe: International Dictionary of Historic Places, Routledge, New York.

-Rinke, Dr. Franziska (2017), Nizhny Novogrod, BoD, Book of Demand, Norderstedt.

-Roberts, Nigel (2011), Belarus, Bradt Travel Guides Ltd., England.

-Salisbury, Yvonne (2009), Mozart, Maria-Mountains the Insiders' Guide of Salzburg, www.insidersguide.com

-Scholz, Albert A. (1964), Silesia Yesterday and Today, Springer-Science, Business and Media B. V., Netherlands. 
ISSN-2199-353X

Online only at http://www.cahij.com/

-Simola, Heikki (1996), Developments in Hydrobiology-The First International Lake Lagoda Symposium, Ed. Heikki Simola, Markku Viljanen, Tatyana Slepukhina, Raj Murthy, Kluwer Academic Publihers, London, Boston.

-Smith, Mark (1996), Ptolemy's Theory of Visual Perception, Transactions of the American Philosophical Society, Vol.86, Part 2, The American Philosophical Society, Philadelphia.

-Stantury, John\&Madsen, Palle (2005), Restoration of Boreal and Temperate Forests, Crc Press, New York.

-Rudgley, Richard (1999), The Lost Civilizatipn of the Stone Age, A Touchstone Book, Published by Simon\&Schuster.

-Strzelczyk, Jerzy (2016), Mieszko Pierwszy, Chrzest i Początki Polski, Wydawnictwo Poznańskie, Poznań.

-Şeşen, Ramazan (2000), “Şerîf İdrîŝ̂”, TDV İslâm Ansiklopedisi, Cilt. 21, ss. 493 495.

-Tacitus (1973), The Annals of Imperial Rome, Penguin Classics.

-Thomas, Alfred (1998), Anne's Bohemia: Czech Literature and Society, 1310-1420, Medieval cultures, Vol.13, University of Minnesota Press, Minneapolis, London.

-The Russian Primary Chronicle (ty), Laurention Text, Trans: Samuel Hazzard CrossOlgerd P. Sherbowitz-Wetzor, The Medieval Academy of America, Cambridge, Massachusetts.

-The Ukranian Quarterly (1949), Vol.5, Ukranian Congress Committee of America.

-Urbańczyk, Przemysław (2008), "Slavic and Christian Identities During Transition to the Polish Statehood", pp. 207-222. Franks, Northmen and Slavs: Identities and State Formation in Early Medieval Europe, UCLA Center for Medieval and Renaissance Studies, Vol. 5. Ed. IIdar, H. Garipzanov \& Patrick J. Geary \& Przemysław Urbańczyk, Brepols, Belgium.

-Verwijmeren, Joris\&Wiering, Mark (2007), Many Rivers to Cross, Cross Border Cooperation in River Management, Eburon Delft, Amsterdam.

-Vincent, C. Paul (1997), A Historical Dictionary of Germany's Weimar Republic, 1918-1933, Ed. Harry Ritter, Greenwood Press, Westport, Connecticut, London.

-Voipio, Aarno (1981), The Baltic Sea, Elsevier Oceanography Series, Istitute of Marine Research, Helsinki, Finland, Elsevier Scientific Publishing Company, NewYork. 
ISSN-2199-353X

Online only at http://www.cahij.com/

-Warner, David A. (2001), Ottonian Germany, The Chronicon of Thietmar of Merseburg, Manchester University Press, Manchester, New York.

-Webber, Christopher (2001), The Thracians, 700 BC-AD 46, Bloomsbury, United States of America.

-Weinandy, Thomas G.\&Keating, Daniel A. (2003), The Theology of St. Cyril of Alexandria, A Critical Appreciation, T\&T Clark, A Contimum Imprint, London, New York.

-Whitton, F. E. (1917), History of Poland, From the Earliest Times to the Present Day, London Constable and Company Ltd., London.

-Wolff, Larry (2001), Venice and the Slavs, The Discovery of Dalmatia in the Age of Enlightment, Stanford University Press, California.

-The World of the Slavs, Studies on the East, West and South Slavs: Civitas, Oppidas, Villas and Archaelogical Evidence ( $7^{\text {th }}$ to $11^{\text {th }}$ Centruies A.D.), The Institute of History, Monographs, Vol. 64, Belgrade.

-Zamoyski, Adam (1987), The Polish Way, A Thousand-Year History of the Poles and Their Culture, John Murray Publishers Ltd., Great Britain.

\section{İnternet Kaynakları}

-www.ancient.eu

-www.ancient.literature.com

-www.britannica.com 
ISSN-2199-353X

Online only at http://www.cahij.com/

\section{RESIMLER}

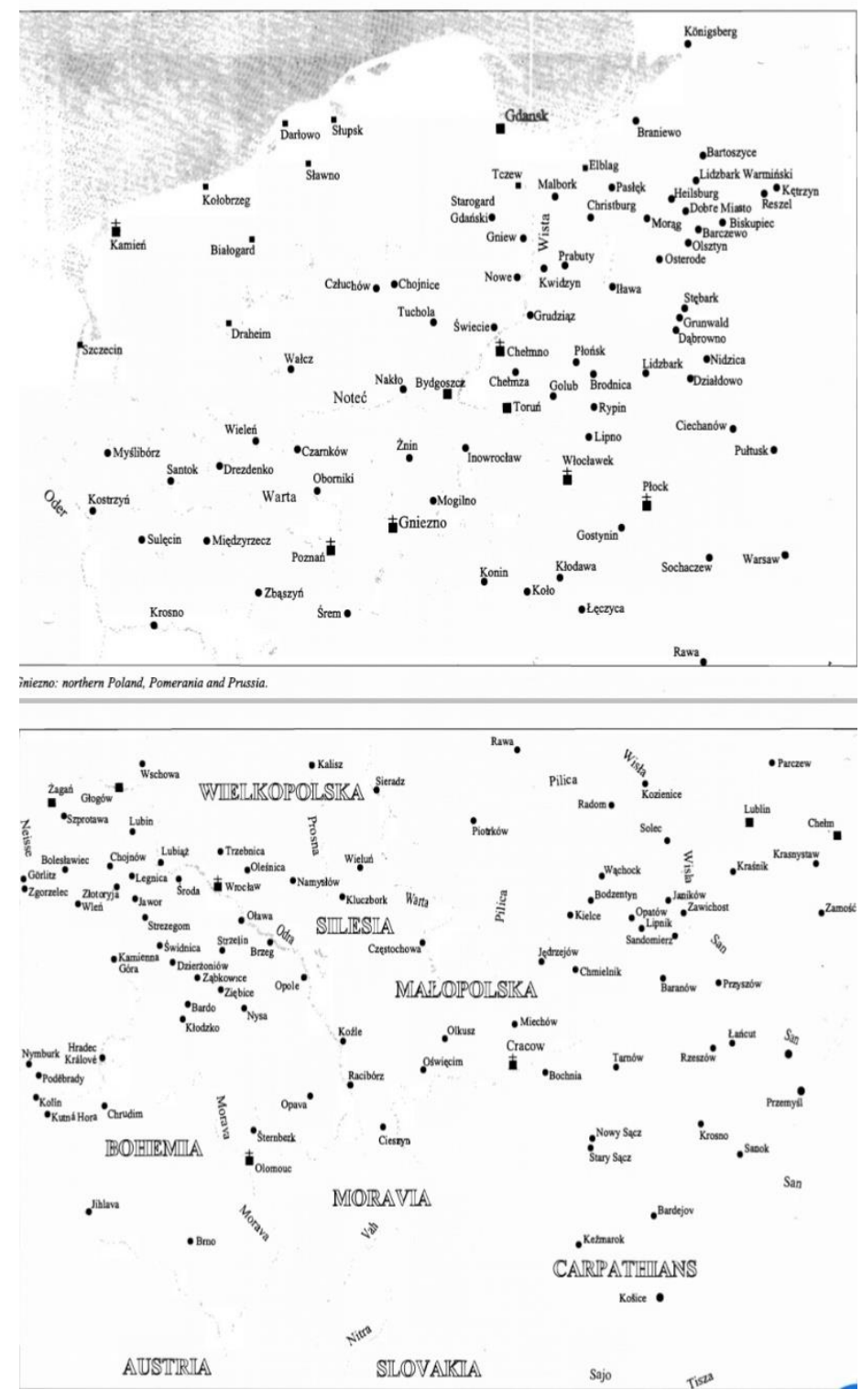

Resim 1: Kraków: Güney Polonya. Macar ve Bohemya Krallıkları ${ }^{126}$

126 Długosz, 1997: XXIX. 


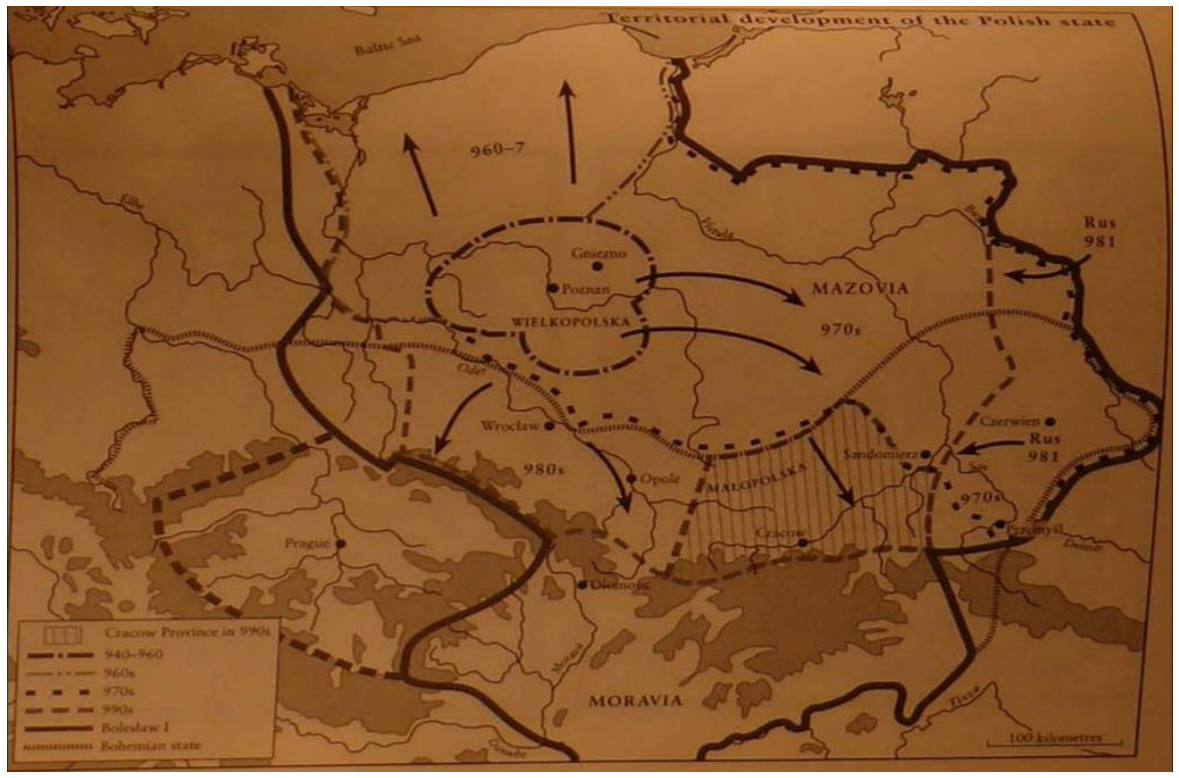

\section{Resim 2: 990’larda Kraków Prensliğgi ${ }^{127}$}

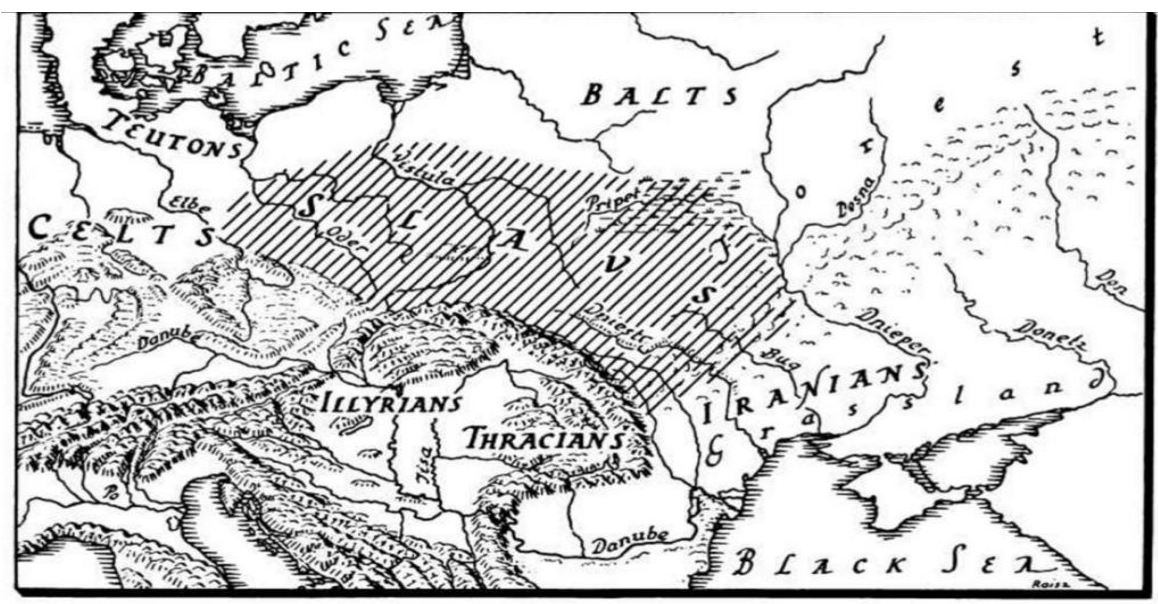

The Original Habitat of the Slavs according to K. Yazdzewski

Resim 3: Yazdewski’ye Göre Slavların Habitatı ${ }^{128}$

127 Barford, 2001: 391.

${ }^{128}$ Dvornik, 1956. 9. 

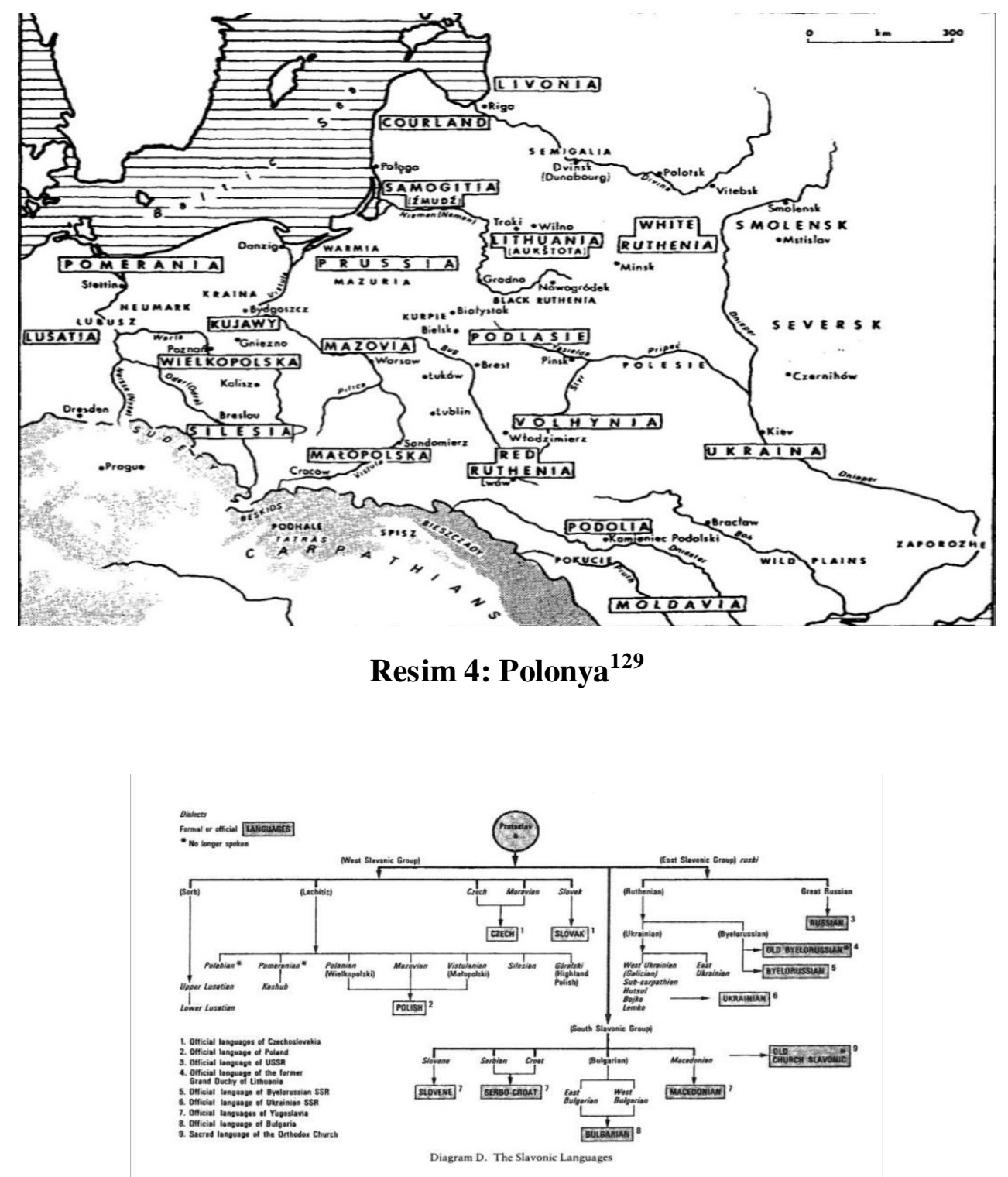

Resim 5: Slav Dilleri ${ }^{130}$

${ }^{129}$ Davies, 2005: 2.

${ }^{130}$ Davies, 2005: 42. 


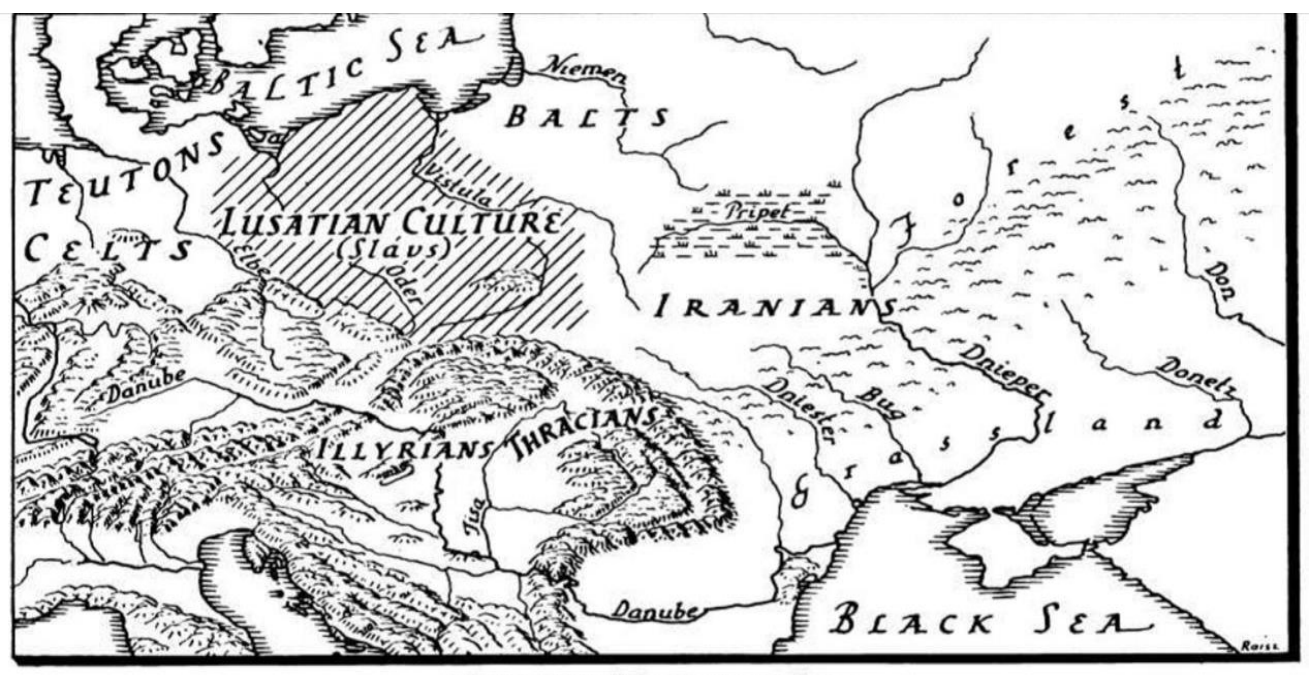

The Territory of the Lusatian Culture

\section{Resim 6: Lusetya Kültür Bölgesi ${ }^{131}$}

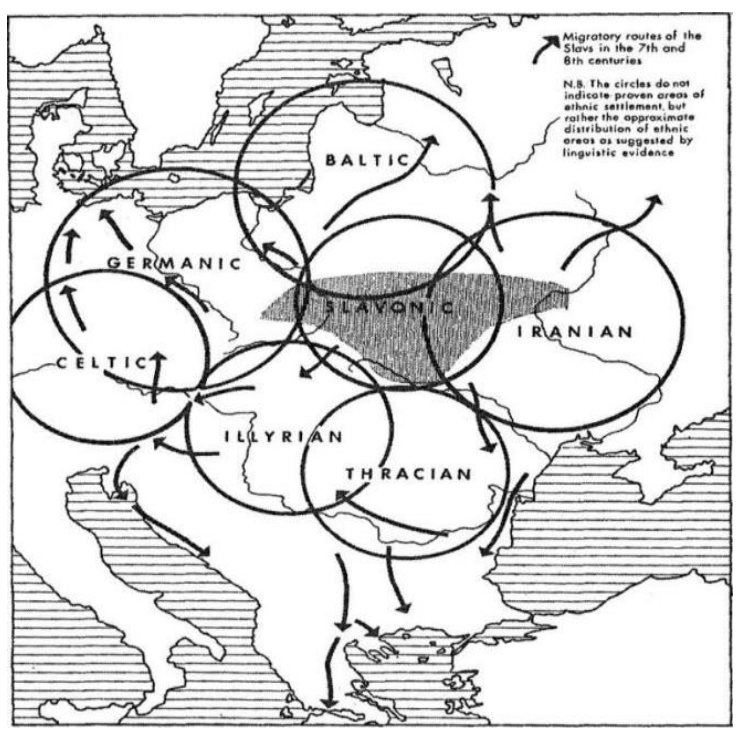

Resim 7: Slavların Atalarının Anavatanları ${ }^{132}$

${ }^{131}$ Dvornik, 1956: 11.

132 Davies, 2005: 38. 


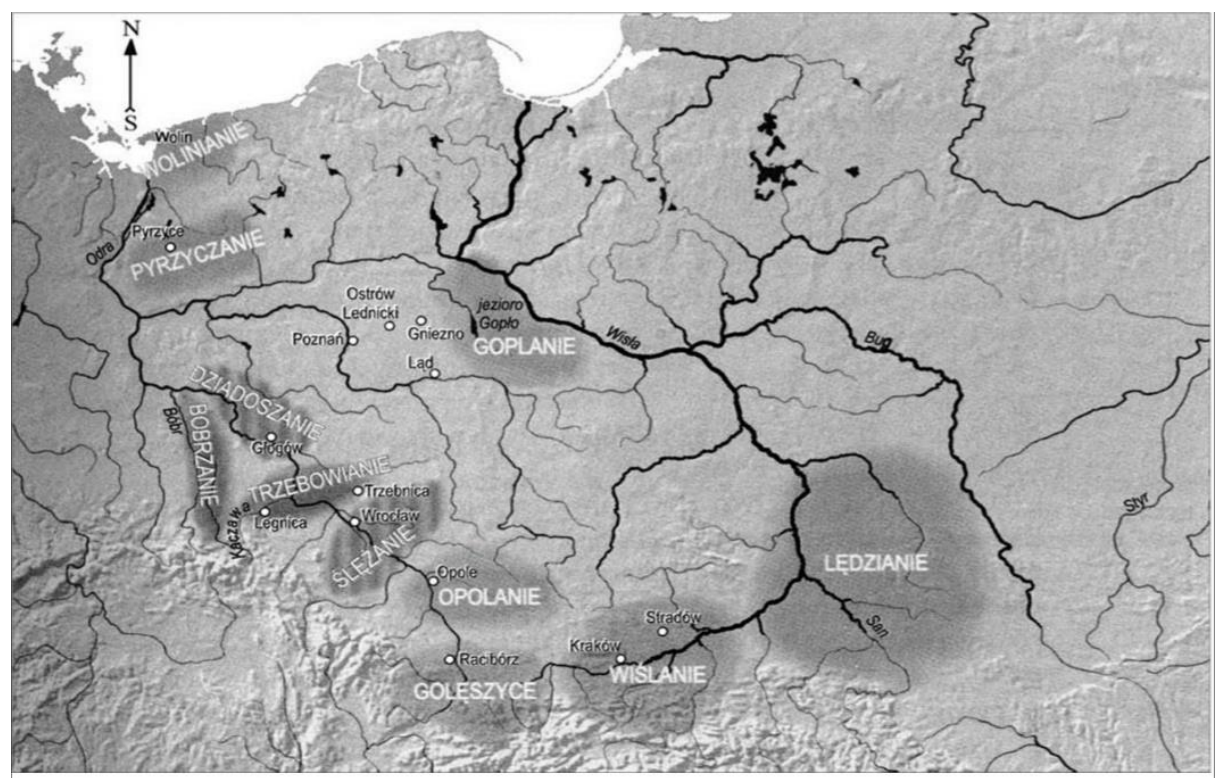

Resim 8: Piast Hanedanlığı Öncesi Kabileleri ${ }^{133}$

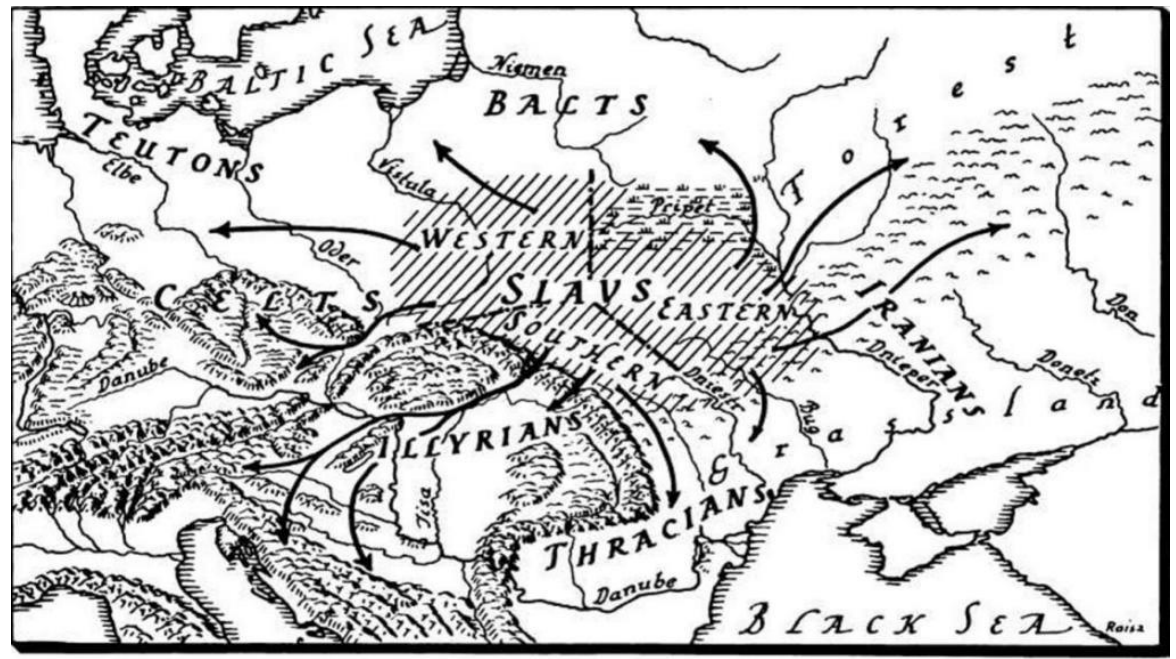

The Original Habitat of the Slavs according to L. Niederle (Slovanski starozitnosti)

Resim 9: Niederle’ye Göre Slav Habitatı ${ }^{134}$

${ }^{133}$ Urbanczyk, 2008: 212.

${ }^{134}$ Dvornik, 1956: 7. 
ISSN-2199-353X

Online only at http://www.cahij.com/

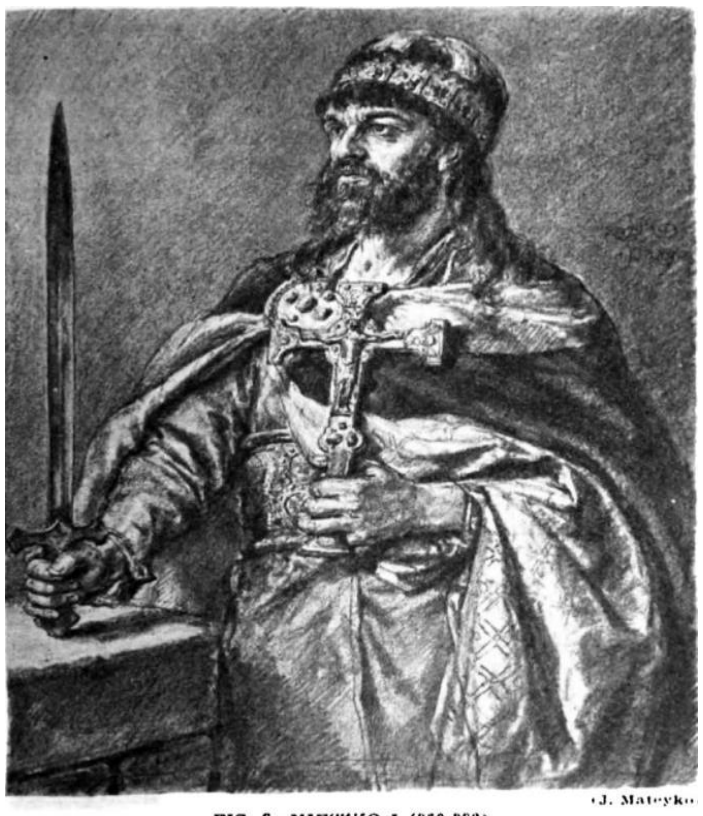

FIO. 8-MIESZKO I (960-982)

\section{Resim 10: Dük I. Mieszko ${ }^{135}$}

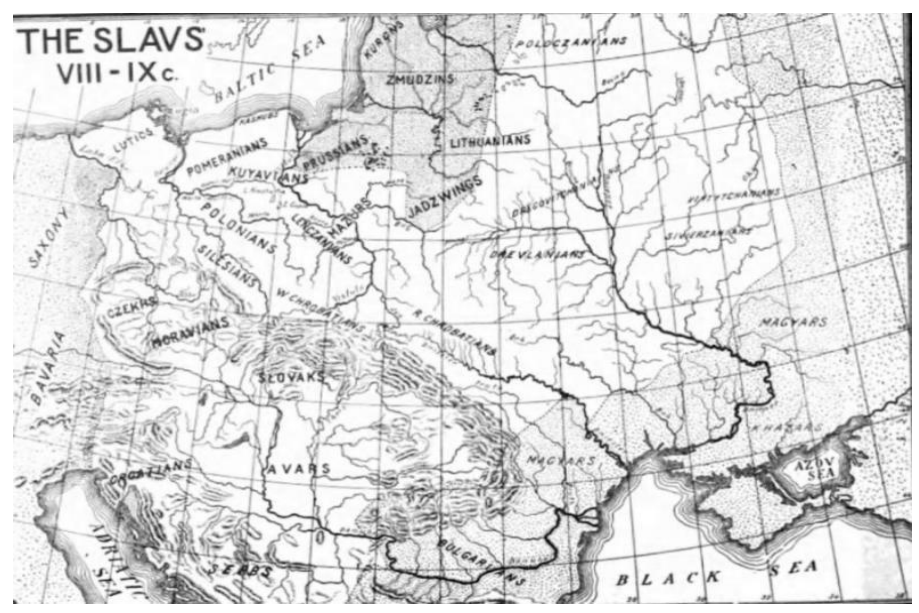

Resim 11: VII. Yüzyılda Slavlar ${ }^{136}$

${ }^{135}$ Lewinski-Corwin, 1917: 13.

${ }^{136}$ Lewinski-Corwin, 1917: 2. 